Pamiętnik Literacki 2018, 4, s. 125-163

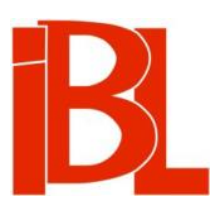

\title{
Mars za Wenerą skryty. Jeszcze jedna próba rozwiązania "Gadki" Jana Kochanowskiego
}

Ewa Cybulska-Bohuszewicz 
Pamiętnik Literacki CIX, 2018, z. 4, PL ISSN 0031-0514

DOI: $10.18318 / \mathrm{pl} .2018 .4 .9$

EWA CYBULSKA-BOHUSZEWICZ Instytut Badań Literackich PAN, Warszawa

\section{MARS ZA WENERA SKRYTY JESZCZE JEDNA PRÓBA ROZWIĄZANIA „GADKI” JANA KOCHANOWSKIEGO}

Dla Krystyny Wilczewskiej: z wdzięcznościa

Powodem napisania tego artykułu jest - trwająca już czas niemały - dyskusja na temat (domniemanego) rozwiązania gadki, jaką onegdaj zadał Jan Kochanowski wdzięcznym wielbicielom swego poetyckiego dowcipu. Nie wiemy, czy współcześni pisarzowi admiratorzy owego talentu potrafili rozwikłać ją w lot, czy też biedzili się ze znalezieniem odpowiedzi tak, jak biedzimy sie z tym my: badacze literatury dawnej. I to już od kilku pokoleń. Rzecz cała zamyka się w zaledwie kilku wersach:

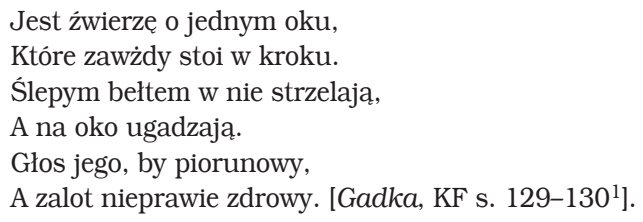

Tych kilka wersów rozpalało umysły, ale chyba jeszcze bardziej - wyobraźnię (znakomitych!) czytelników-badaczy przez całe dziesięciolecia trwania dyscypliny zajmującej się analizą tekstów staropolskich. Bo też wbrew pozorom, jakie może stwarzać zwięzła forma, jest się nad czym zastanawiać. Trzeba powiedzieć, że co najmniej kilka z 6 linijek wierszowych utworu pozostaje dla współczesnego czytelnika swego rodzaju zagadką, rzec można, iż Kochanowski przygotował kilka „gadek” w jednej Gadce i to dlatego tak trudno w sposób jednoznaczny odczytać ten tekst, nawet rodzi się wątpliwość, czy istnieje rzeczywiście jedno wyjaśnienie. Spróbujmy

Skrótem KF odsyłam do: J. K o c h a n o w s ki, Fraszki. Kraków 1584. Stosuję również inne skróty odnoszące się do dzieł tego autora: KFr = Fragmenta, albo Pozostate pisma. Kraków 1590; KP = Pieśni. Kraków 1586; KPs = Psałterz Dawidów. Kraków 1579. Ponadto do artykułu wprowadziłam też inne skróty: M = J. M ą c zy ń s k i, Lexicon Latino-Polonicum [...]. Królewiec 1564. - R = M. Rej, Figliki. Kraków 1562. - RW = M. Rej, Wizerunk własny żywota człowieka poczciwego [...]. Kraków 1560. - S = M. Stryj kow ski, Przesławnego wjazdu do Krakowa i pamięci godnej koronacyjej Henryka Walezyjusza [...]. Kraków 1574. Liczby lub oznaczenia po skrótach wskazują stronice bądź karty. Wszystkie cytaty podaję za edycjami pierwszymi, a nie (jak to jest w zwyczaju) za edycjami krytycznymi. Postępuję tak świadomie, ponieważ moją argumentację opieram na materiałach stanowiących kartotekę Stownika polszczyzny XVI wieku, którą tworzą w zdecydowanej większości teksty oryginalne. Ortografia i interpunkcja w cytatach zostały uwspółcześnione. Wszystkie podkreślenia $\mathrm{w}$ artykule - E. C.-B. 
zatem może „podejść” Gadkę tak, jak rozwiązuje się proste zadania matematyczne, a więc - wypiszmy dane i szukane. Co wiemy o enigmatycznym „Źwierzu” z cała pewnością? Otóż niewiele: jest to stworzenie bez wątpienia jednookie, wyróżniające się „głosem piorunowym” i „zalotem nieprawie zdrowym”; wiemy również, że „zawżdy stoi w kroku”, jacyś ludzie zaś strzelają do nieszczęśnika ślepym bełtem i „na oko ugadzaja”" ${ }^{2}$. Jak się wszakże okazuje, nie jest prosta ta arytmetyka, ponieważ już w danych, a zatem w tym, co wolno nam przyjąć za pewnik - kryją się zawiłości, którym nawet matematyka nie poradzi. Cóż to bowiem znaczy, że „stoi w kroku”? Czy to, iż stoi rozkraczone, czy też iż jest umiejscowione w kroku (lege: kroczu)? A może, że stoi w pozycji bojowej? A może jedno i drugie? Wszystkie odpowiedzi są poprawne? Co należałoby rozumieć przez „zalot nieprawie zdrowy”? Czy bez wątpienia zdrowy? Czy też - przeciwnie - niezdrowy? Wreszcie: jak można strzelać ślepym bełtem, ale „ugadzać”? I czy „ugadzać”, a więc trafiać „na oko”, trzeba by odczytać jako - 'trafiać celnie, bez pudła'; czy raczej - po prostu - trafiać biedne zwierzę w oko?

Wszystkie te wiadome, w gruncie rzeczy zaś niewiadome, wymagałyby szerszego omówienia, a konkretnie - ustalenia: czy potrafimy faktycznie znaleźć jakąś jedna prawdopodobną wersję, sytuację idealną (np. fizycy wykonuja pewne obliczenia z pominięciem czynników zakłócających, jak choćby siły tarcia), w której owe niewiadome będą spełniały warunki i dadzą jednoznaczny wynik tego filologicznego równania? I czy odpowiedź w taki sposób uzyskaną rzeczywiście będzie można przyjąc za wiarygodną? Aby to ustalić, prześledzę najpierw rozwiązania, jakie zaproponowali moi poprzednicy, a następnie przedstawię swoją koncepcję, która pozostaje $\mathrm{w}$ związku $\mathrm{z}$ owymi prymarnymi - względem moich przemyśleń próbami rozwikłania XVI-wiecznej zagadki.

Propozycje rozwiązania Gadki wyszły od badaczy takiej miary co: Józef Przyborowski, Stanisław Łempicki, Julian Krzyżanowski, Janusz Pelc. Zwłaszcza dwóch ostatnich powszechnie uważa się za nestorów staropolskiego literaturoznawstwa godnych najwyższego szacunku. Swój udział w dyskusji na temat rozstrzygnięcia zagadki miał także Marian Pankowski. Głos zabrali również Tomasz Nastulczyk i Piotr Oczko, ale nie zaproponowali oni żadnego rozwiązania, a jedynie ograniczyli się do swoistego dementi, jakoby fraszka miała być przedstawieniem homoseksualnego aktu miłosnego ${ }^{3}$. Najnowsze próby wyjaśnienia jej sensu przedstawili uczeni przynależący do młodszego pokolenia: Joanna Duska, Radosław Grześkowiak oraz Maciej Eder ${ }^{4}$. Ci ostatni dwaj uczeni pracowicie nie tylko zebrali i przeanali-

2 Należałoby tu wspomnieć, co podkreśla też R. Gr ześ k ow i a k w swoim artykule O dupie Maryni. Rozwiazywanie „Gadki” Jana Kochanowskiego („Odrodzenie i Reformacja w Polsce” 2016, s. 118), iż w Słowniku polszczyzny Jana Kochanowskiego (Red. M. Ku c ała. T. 5. Kraków 2012, s. 118) nadmienia się, że poeta w Gadce użył słowo „źwierzę” w sensie przenośnym, nie objaśniono go jednak. Przy wyrazie „oko” nie znajdujemy podobnego komentarza, co oznacza, że trzeba go odczytywać dosłownie (Słownik polszczyzny Jana Kochanowskiego, t. 3 〈2003〉, s. 314-315).

3 T. Na stulczy k, P. O c z k o, Homoseksualność staropolska. Przyczynek do badań. Kraków 2012, s. $80,447$.

4 J. D u s k a, Tajemnicza „Gadka” z księgi III „Fraszek” Jana Kochanowskiego. Rozwiazanie zagadki. W zb.: Wiązanie sobótkowe. Studia o Janie Kochanowskim. Red. E. La s o c iń s ka, W. P a w- 
zowali wszystkie dotychczasowe próby rozwikłania czarnoleskiej enigmy, ale także prześledzili wiele tekstów źródłowych (w tym rzadkich rękopisów) z XVI i XVII wieku, które wydają się z fraszką Kochanowskiego złączone, ich lektura zaś winna naprowadzać na słuszne (jak przyjmują autorzy) rozwiązanie, jakie stanowi żeński organ płciowy. Trzeba przyznać, że wywody Grześkowiaka i Edera mają solidne podstawy (oprócz tekstów literackich powołują się oni również na ustalenia leksykograficzne, a nawet zapisy etnograficzne) i sa przekonujące. Ze zrozumiałych powodów nie będę tu streszczała całości tych tekstów. Poprzestanę tylko na przypomnieniu rozwiązań, jakie badacze ci proponują i do których chciałabym się odnieść.

Rzeczywiście, jeśli założyć, iż rozwiązanie zagadki jest nieobyczajne, to wydaje się nim prędzej żeński niż męski anus. Pierwsza wspomina o tym już Duska, która wszakże ostatecznie przychyla się ku temu, że fraszka nie ma wydźwięku obscenicznego, ale raczej skatologiczny, i że dotyczy przenośnego stolca wychodowego ${ }^{5}$. Praca Duskiej jest, jak zaznaczył Eder, interesująca oraz błyskotliwa, ale - co z kolei wypunktował Grześkowiak - pojawiają się w tej propozycji elementy, które nie pasują do czarnoleskiego „równania”. Najbardziej błędne założenie autorki odnosi się do tego, iż „głos piorunowy” (podstawowy i niezaprzeczalny atrybut zwierzęcia opisanego przez wieszcza) w świetle jej interpretacji oderwano od tego, kto go wydaje (zwierze), a przypisano temu, kto do zwierzęcia strzela („głos piorunowy" to według Duskiej dźwięk towarzyszący wypróżnieniu). Pozostałe argumenty przemawiajace za odrzuceniem takiego rozwiąania wymienił w swym artykule Grześkowiak i sądzę, że są one przekonujące ${ }^{6}$. Co jednak ciekawe, choć autor polemiki dostrzegł nieścisłość w interpretacji wątku „głosu piorunowego” w pracy Duskiej, to - trzeba przyznać - sam również nie do końca sobie z nim poradził. Stwierdza bowiem coś, z czym trudno się zgodzić:

Z punktu widzenia fizjologii końcowy dystych czarnoleskiej zagadki wydaje się trywialny: taki sam odgłos towarzyszy powietrzu uchodzącemu z pochwy po stosunku, jak i puszczaniu gazów jelitowych $[\ldots]^{7}$.

Odnotował to Krzysztof Obremski w zwięzłym artykuliku Glosa polemiczna do Radosława Grześkowiaka „Rozwiąywania "Gadki" Jana Kochanowskiego”. I ma Obremski bezsprzecznie rację: nie da się porównać odgłosu powietrza wydobywającego się po stosunku z pochwy do dźwięku grzmotu. Nie jestem też zupełnie przekonana, iż (jak chce Grześkowiak) dochodziło do takiego utożsamienia obu kobiecych otworów, że w istocie ich precyzyjne rozgraniczanie nie miało żadnego znaczenia, ponieważ:

Kiedy zbrojni w mędrca szkiełko i oko zaglądamy pod kobiecą suknię, by skrupulatnie różnicować

la k. Warszawa 2015. - Gr z e ś k o wi i k, op. cit. - M. E d e r, Zagadkowe „źwierzę ojednym oku”, czyli o fraszce III 78 Kochanowskiego. „Prace Filologiczne. Literaturoznawstwo” 2017, nr 7.

5 D u ska, op. cit., s. 354-355.

6 Grześkowiak, op. cit., s. 112-119.

7 Ibidem, s. 136.

8 K. Obre m ski, Glosa polemiczna do Radosława Grześkowiaka „Rozwiazywania "Gadki" Jana Kochanowskiego”. „Odrodzenie i Reformacja w Polsce” 2017. 
znalezione tam otwory, łatwo zapomnieć, że [sa] one na tyle blisko, iż gdy jeden śmierdzi, to i drugi pachnieć nie będzie, a kiedy jeden grzmi, ucho nie wychwyci, który9.

Choć trudno zaprzeczyć oczywistemu faktowi, iż oba otwory znajdują się blisko siebie, to już „głos piorunowy” może wydawać tylko jeden $z$ nich, czego dowodzą chociażby Figliki, pokazujące, że (mówiąc językiem Reja) pierdzą kobiety i mężczyźni, a przecież ci ostatni dysponują tylko jednym otworem, zatem nawet metodą dedukcji można dojść do wniosku, że „głos piorunowy” przysługuje „dupie” (w znaczeniu: odbytowi) - to atrybut nierozerwalnie $z$ nią związany. U Reja jest to często zabawnie odmalowywane, np. w naprawdę udanym figliku Co sowę zjadt:

\author{
Jednego z naszej braciej sową nakarmili, \\ $Z$ korzeniem na półmisek pięknie przyprawili. \\ Potym głowę przynieśli, społu i z nogami, \\ A ten rzecze: „Jużci źle, panie, racz być $z$ nami”. \\ I pierdni e silnym głosem: „Otożci już huka, \\ A kędy by wylazła pewnie dziury szuka. \\ Ale wy tam na tyle bądźcie pilni dzieci, \\ Łapajcież więc zębami, boć pewnie wyleci”. [R k. 26v]
}

W cytowanym utworze niewątpliwie jest mowa o puszczaniu wiatrów (pojawia się czasownik „pierdnaćc”). Zostało ono w wierszyku Reja ukazane za pomocą konceptu: porównane do głosu sowy, jakoby zagubionej w czeluściach ciała tego, kto ją zjadł. Ptak, pohukując, poszukuje wyjścia i stąd owe zaskakujące dźwięki. Ponieważ zaś mężczyzna jest wyposażony tylko w jeden otwór (odbytnicę), „,sowa” nim właśnie wylatuje. A oto figlik Mą̇ co żonę chwalit, który dowodzi, że „trzaska” kobieta i że nie ma to nic wspólnego z odbywaniem stosunku. Zatem „głos piorunowy” i akt seksualny sa czymś rozdzielnym, bo kobieta „trzaska”, kiedy zachodzi potrzeba (nawet gdy śpi), a nie kiedy ktoś napełni powietrzem ${ }^{10}$ jeden $\mathrm{z}$ jej otworów ${ }^{11}$ :

\footnotetext{
Kupiec żonę przed panem chędogą wysławiał,

By kiedy tr za s n ąc miała, tego nie doznawał.

Pan, bacząc, iż pijany, chłop twardo dosypiał,

Żartując, dukatów sto z mieszka mu wysypał.

Chłop, myśląc o pieniądzach, kilka nocy nie spał,

A iż pani pi erdziała, teraz prawie doznał.

Pan, wracając pieniądze, pytał: „Pi erdzi żona?”

„Ach, panie, daj ją diabłu, śmierdzi jej z ogona”. [R k. 5v]
}

W wierszyku tym pojawiają się synonimiczne czasowniki oznaczające puszczanie wiatrów. Są to: „pierdzieć” i „trzasnać”. Pierwszy z nich wiąże się wyłącznie z czynnością wypuszczania wiatrów, co odnotowuje Stownik polszczyzny XVI wieku (dalej: SpXVI) ${ }^{12}$. Czasowniki „trzasnąč, ale też „trzaskač”, w interesującym nas kontekście nie tylko tyczą się puszczania gazów (poświadcza to materiał wspomnia-

Zob. ibidem.

11 Nie jest to zreszta jedyny w zbiorze utwór o pierdzacej kobiecie, zob. też Jako żona męża żałowała (R k. 12v) i Baba, co pierdziała u krzcielnice (R k. 31).

12 D. Dyki el-Ruch a, Pierdzieć. Hasło w: Stownik polszczyzny XVI wieku. T. 24. Red. M. R. M ay e n owa, F. Pe płow ski. Warszawa 1996, s. 88. W tomie tym znajdują się także leksemy z rodziny opisywanego czasownika. 
nego słownika ${ }^{13}$ ), lecz bardzo często bywają odnoszone do odgłosu pioruna, co może potwierdzać, że między tymi dwoma odgłosami istnieje związek odpowiedniości. Oto przykłady. Oprócz Figlików słowo „trzaskać” (= 'pierdzieć) znajdujemy w Żywocie Ezopa Fryga Biernata z Lublina:

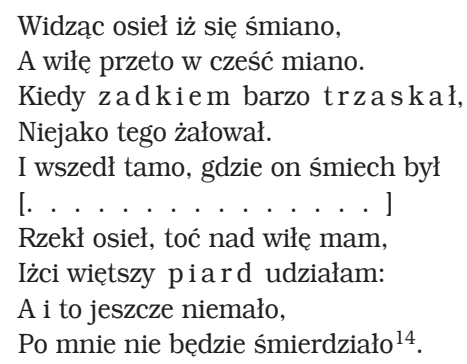

Związek zaś tego słowa $z$ piorunem poświadczają rozliczne teksty, których nie sposób tu przytoczyć, ale istotne jest to, że wśród nich mamy także te autorstwa Kochanowskiego (nie tylko w Pieśniach, Fraszkach, lecz też np. w Psałterzu Dawidowym):
Strach patrzać na to częste połys kanie:
A prze to srogie obłoków trzaskanie
Kłada się lasy, a pi or un gdzie zmierzy,
Źle nie uderzy. [Pieśń I. Księgi wtóre, KP s. 31]

We Fraszkach (Do Wojewody) pojawia się również ciekawe słowo „trzaskawica” (tj. 'grzmot, który powoduje trzaskanie', a więc huk, analogicznie jak błyskawica wywołująca błysk, błyskanie się), dziś już nie istniejące, ale dobrze poświadczone przez teksty wczesnego polskiego renesansu ${ }^{15}$ :

\section{[...] zewsząd powstają \\ Srogie wiatry, zewsząd strachu ludziom dodają \\ Chmury czarne, gradu pełne, i trza skawice [...]. [KF s. 85]}

I jeszcze dwa zwięzłe przykłady, których dostarcza Lexicon Latino-Polonicum [...] Jana Mączyńskiego:

Et Bruta fulmina, apud Plinium: Pi o r u n o w e u d e rze n i e, które żadnemu nie przepuszcza, to jest nie ma na nikogo osobliwego względu, wszystki zarówno straszy, albo, która bez wieści a błyskania jednym razem trzaśnie. [M k. 27b]

Fulgor, fulgoris: Jasność. Fulgores \& tonitrua: Łys k a nie i trzaskanie. Fulminat: Trzas ka, grzmi, piorun bije. [M k. 139b]

Już tylko wybrany i przedstawiony tu materiał dobrze ilustruje tezę, iż dźwięk pojawiający się podczas puszczania wiatrów może być tożsamy z „głosem piorunowym”. A zatem stwierdzenie, że odgłos ten miałby stanowić efekt „powietrza uchodzącego z pochwy po stosunku”, należy odrzucić jako błędne. Nie przeczę, iż zja- 
wisko tzw. wiatrów pochwowych (łacińskie określenie stosowane przez ginekologów to „flatus vaginalis”) istnieje. Ale trudno jest je porównać do dźwięku grzmotu, gdyż porównanie takie wyklucza już sama anatomia ${ }^{16}$. Ponadto wydaleniu owych gazów nie towarzyszy żaden „zalot” (są one bezwonne). Co więcej: zjawisko to nie pojawia się zawsze, nie jest czymś powszechnym, nie u każdej kobiety występuje, trudno uznać je za cechę charakterystyczną żeńskiego organu płciowego. Należy także zaznaczyć, iż o fenomenie tym wedle wszelkiego prawdopodobieństwa jeszcze nie słyszano w czasach powstawania Gadki. Omawia się go bowiem od niedawna, a piśmiennictwo, nawet specjalistyczne, dotyczące owego tematu, jest wciąż skąpe. Wydostawanie się powietrza $\mathrm{z}$ pochwy współcześnie traktuje się wciąż jako problem, i to bardzo wstydliwy. Zważywszy poziom XVI-wiecznej wiedzy, wydaje się, że Kochanowski nie miał w ogóle pojęcia o istnieniu podobnego zjawiska, nie był więc w stanie go opisać. Mówiąc dosadnie: dla ludzi żyjących w epoce renesansu pierdzieć mogła tylko dupa i czynność ta bywała wielokrotnie przedmiotem żartów poetyckich. W Gadce chodzi zatem bezsprzecznie o „pierdnięcie właściwe”, które wydobywa się wyłącznie $z$ „pośledniej dziury”, odbywa się zaś to tak samo u obu płci. Jeśli więc już przyjąć, że przy stosunku rozlega się jakiś „głos piorunowy”, to należy jednak go przypisać właściwemu otworowi i uznać za nieco może krępujący wypadek przy akcie miłosnym. Sądzę, iż dotyczy to także defloracji, o której wspomina Grześkowiak, powołujący się na Sztukę obłapiania Aleksandra Fredry. Pierwszemu zbliżeniu ma towarzyszyć „pierd impetyczny” czy też „huczny pierd” ${ }^{17}$, jednak uważna lektura tekstu pozwala stwierdzić, iż wcale nie musi być tak, że wydobywa się on z pochwy. Równie dobrze można przypisać go „przyrodzonej dziurze”. Wydaje się to bardziej sensowne, zwłaszcza w świetle omawianego utworu, gdyż pochwa jest w momencie wydobywania się owego „pierdu” - ni miej, ni więcej - zatkana (wyraźnie wynika to $z$ tekstu), więc powietrze zwyczajnie nie ma jak ulecieć tą drogą.

Inną wskazówką, która pozwala właściwie zlokalizować analizowane zjawisko, jest to, że Fredro, opisując rozdziewiczanie, wspomina o bliskim sąsiedztwie waginy i odbytnicy, przysparzającym kłopotu, zwłaszcza mężczyznom niewprawnym w ars amandi. Jak konstatuje autor prostolinijnie, „pierd impetyczny” może „Dać kontuzyję i okopcić jaja" ${ }^{18}$. Takie właściwości owego zjawiska pozwalają stwierdzić, że chodzi o zwykłe wypuszczanie wiatrów, a nie o dźwięki związane jakoby z przerwaniem błony dziewiczej (odbywa się to bowiem bezgłośnie). Poświadczaja to

Mówiąc zwięźle: w odbycie znajduje się bardzo silny mięsień, tzw. zwieracz, i aby powietrze wyszło na zewnątrz, musi pokonać opór tego mięśnia, co daje wrażenie akustyczne. Pochwa, w odróżnieniu od odbytnicy, w taki mięsień nie jest wyposażona, więc efekt dźwiękowy, nawet jeśli się pojawia, brzmi mniej spektakularnie. Wiatry z pochwy bywają sygnałem ginekologicznych nieprawidłowości (związanych zwykle $z$ osłabieniem mięśni, wypadaniem macicy albo z przetoką). Najczęściej nie oznaczają niczego złego (pojawiają się w różnych sytuacjach, np. podczas ćwiczeń gimnastycznych, po porodzie, po czym, kiedy pochwa ulegnie obkurczeniu, zanikają, ale zdarza się, iż się utrzymuja). Zob. S. Alla h din, Flatus vaginalis as distressing symptom. „International Journal of Colorectal Disease" 2011, z. 11, s. 1493. - J. Herman, T. Kościński, U. Piekarska-Skowrońska, M. Dopierała, Przetoka odbytniczo-pochwowa jako powikłanie przedniej resekcji odbytnicy. „Nowa Medycyna” 2015, nr 1, s. 17.

17 A. Fred ro, Pieśń druga. W: Sztuka obłapiania. Poemat $w$ IV pieśniach wierszem z r. 1817. Poprzedza rzecz o Erosie w poezji Fredry. Suwałki 1926, s. 22, w. 88, 80. 
teksty, w których gazy jelitowe są przedstawiane jako dym czy też „para zadkowa”19. Leksyka opisująca to zjawisko okazuje sie przebogata (dotyczy to zarówno polszczyzny XVI, XVIII wieku, jak i współczesności). Słowa: „pierd(ell)”, „pierdzieć”, „pierdzenie" (a także formacje współrdzenne, których jest tak dużo, że nie da się tu wymienić wszystkich, typu: „odpierdzieć”, „przepierdelować”, „spierdzieć 〈się〉”, „wypierdzieć" itd.), semantycznie odnoszą się wyłącznie do wzmiankowanego zjawiska wypuszczania wiatrów, nie pozostawiając miejsca na żadne fantazje ${ }^{20}$. Myślę, iż Grześkowiak niepotrzebnie poszedł tym tropem, zwłaszcza że przytacza teksty wyraźnie naprowadzające czytelnika na tor właściwy, tj. ukazujące anatomię kobiety w sposób jak najbardziej prawidłowy (a więc: dwa otwory, z których każdy ma swoją funkcję i jest inaczej wartościowany). Ową dwoistość uwidocznił badacz np. w epigramie Na panny Jana Andrzeja Morsztyna, gdzie „miech tylni”"21 (czyli 'odbyt') stanowi element wnoszący dysonans, zaburza przyjemność płynącą ze zbliżenia. „Poślednia dziura” kojarzy się negatywnie do tego stopnia, że jest albo pomijana milczeniem (przywołane przez Grześkowiaka tabu nałożone na sferę analną, pojmowana jako „siedlisko” sodomii - grzechu niemego, oraz miejsce, skąd wychodzą z ludzkiego ciała ekskrementy, budzące strach nieomal magiczny ${ }^{22}$ ), albo, jeśli już zostaje wspominana, to $\mathrm{z}$ niesmakiem.

Propozycję godzącą niejako dwa odrębne porządki, a więc: waginalny i analny, przedstawił Eder, również uznający, iż rozwiązaniem Gadki jest niewieści organ płciowy. Badacz (podobnie jak poprzednik) przytacza bogaty materiał źródłowy, który wskazuje na to, jak zacierało się pierwotne znaczenie wyrazów „rzyć” czy „dupa”, jak z pierwotnie bardziej pojemnego semantycznie słowa zmieniło się w wyraz współcześnie rozumiany w zasadzie jednoznacznie: jako tylna część ciała, kojarzona $z$ wydalaniem. Przy czym należy zwrócić uwagę na to, że nawet dzisiejsza, choć o wiele uboższa w sensy - „dupa”, jest dwupłciowa, a zatem tak samo definiowana u kobiety i u mężczyzny, co jest istotne w świetle naszych rozważań. W swoim artykule Eder pokazuje, jak już wspomniałam, ewolucję wyrazów „dupa” czy też „rzyć”. Słuszne wydaje się stwierdzenie, iż pierwotnie słowa te mogły oznaczać nie tylko pośladki/zadek ${ }^{23}$. Uściślając: Eder pisze, że określenie „dupa” dotyczyło także kobiecych organów płciowych i taka ich deskrypcja była możliwa na zasadzie swoistego zacierania sensów czy też ich przeniesienia ${ }^{24}$, wynikającego (jak u Grześ-

M. Si e nnik, Lekarstwa doświadczone [...]. Kraków 1564, k. Vuu4.

Przykładów dostarczają Słownik polszczyzny XVI wieku (zob. odpowiednie, wymienione wcześniej hasła) oraz Kartoteka „Słownika języka polskiego XVII i 1. połowy XVIII wieku” (na stronie: http:// www.rcin.org.pl/dlibra/docmetadata?id=7779\&from=publication 〈data dostępu: 10 IX 2018〉). Dodać można jeszcze inne wyrazy: (ze)bździć, (s)kadzić (się) itp. Leksemy te wciąż pozostają żywe i w większości są używane również współcześnie.

Cyt. za: Grześ kowiak, op. cit., s. 136.

Ibidem, s. 128-131.

Ed e r, op. cit., s. 23-26.

Ibidem, s. 23. Badacz przytacza na tej samej stronicy naprawdę świetny przykład ludowej piosnki, w której młoda dziewczyna tak opisuje proces dojrzewania:

Ciese jo sie, ciese, ze mi cycki rosno, dupa mi sie piórcy, bede dawać wiosną. 
kowiaka) z bezpośredniej bliskości obu żeńskich otworów. Dodałabym, iż w przeciwieństwie do męskich narządów, które są od tyłka wyraźnie oddzielone ${ }^{25}$, u kobiet (anatomicznie) granica ta nie jest aż tak ostra, pochwa znajduje się gdzieś w punkcie między udami, odbytem a pośladkami, zarazem zaś pozostaje jakby integralną częścią rzyci, a nawet wręcz wydaje się schowana w jej obrębie. I to sprawia, że żeński tyłek mógł być rozumiany jako całość, zawierająca pośladki oraz „przyległości” - tj. odbyt i organy płciowe. Przy czym należy podkreślić, że tak postrzegana rzyć, choć funkcjonowała jako jedność, to doskonale zdawano sobie sprawę z jej, by tak rzec - „zawartości”, i różnicowano oba jej otwory, co zostało opisane wcześniej. Nie wolno jej zatem pojmować jako zespołu dwóch otworów na tyle bliskich, że aż dochodzi do zaniku jednego kosztem drugiego ${ }^{26}$. Tylko bowiem jako byt zawierający elementy przeciwstawne jest ona zdolna łączyć - według Edera - pozornie sprzeczne porządki: erotyczny i skatologiczny.

Jeśli przyjmiemy takie oto globalne znaczenie omawianego wyrazu, to zaiste możemy uznać rzyć za najlepszą „kandydatkę” do rozwiązania tajemnicy Gadki, oczywiście pod warunkiem, że założymy, iż odpowiedź jest jedna i wiąże się ze sferą seksualności. W ten sposób otrzymujemy całkiem chyba spójny obraz zwierzęcia, które ma jedno oko (pochwa) i wydaje "głos piorunowy” (odbyt). Z pewnością ktoś może zaprotestować i stwierdzić, że przecież zwierzę w Gadce ma tylko jeden otwór (tak właśnie narodziła się teza, iż Gadka to fraszka o tematyce homoerotycznej). Moim zdaniem, niekoniecznie. Otóż w Gadce nie jest przecież powiedziane, w ile otworów jest zwierzę faktycznie zaopatrzone. Wiemy (bezsprzecznie), że ma jedno oko i że w jakimś sensie grzmi, co pozwala dokonać takiego przyporządkowania, jakie tu właśnie zaprezentowano, bez ryzyka nadinterpretacji. Niemniej pozostawiam tę kwestię nierozstrzygniętą, gdyż istnienie w rzyci kobiecej dwóch otworów rzeczywiście może budzić uzasadnione wątpliwości interpretacyjne. To właśnie fakt, iż zadek żeński ma dwie dziury, stał się punktem wyjścia dla hipotezy, że z Gadka łączy się rozwiązanie odsyłające do praktyk homoseksualnych (wszak w tyłku męskim znajduje się tylko jeden otwór). Zwolennikiem owej hipotezy był Pankowski, przychylał się ku niej Pelc, a kilka lat temu wspomniał o niej także Piotr Sobolczyk w artykule Homoerotyczny barok? Wokót dwóch wierszy Villamediany ${ }^{27}$. W pracy tej autor (jedynie w przypisie) przedstawia omówienie utworu Kochanowskiego. Wszakże zupełnie lekceważy znaczenie staropolskiej leksyki i podaje np., iż „zalot nieprawie zdrowy” to sodomia, „Zwierzę” zaś to sodomita, gdyż pod pojęciem sodomii rozumiano, jak stwierdza, również stosunki seksualne ze zwierzętami ${ }^{28}$. Cały komentarz Sobolczyka (w części dotyczącej Gadki) jest pełen tego rodzaju błędów. Co jednak warto odnotować, autor wiarygodnie omawia, w jaki sposób rzeczownik „oko" został powiązany ze sferą seksualności, odnotowuje, że to mogło się dokonać za pośrednictwem łaciny (wspomniane przez Edera „culus” i „oculus”), języka włos-

Widać to np. w Rozmowach Salomona z Marchołtem (Przekł., oprac. M. E d e r. Wrocław 2014). Gdy Marchołt wypina się na króla, wystawia mu „rzyć i jaj〈ca〉” (s. 116). W przypadku, kiedy kobieta dokonuje takiego aktu, jest mowa tylko o rzyci (zob. choćby wspomniane Figliki Reja). Zob. Gr z eś k o wia k, op. cit., s. 137: „Wystarcza krok w tył, by dwa różne żeńskie otwory zastąpił jeden, właściwy".

27 P. S o b olc zy k, Homoerotyczny barok? Wokół dwóch wierszy Villamediany. „Fraza” 2014, nr 3.

28 Ibidem, s. 179, przypis 28. 
kiego albo hiszpańskiego ${ }^{29}$. Trudno jednak uchwycić moment, kiedy owo skojarzenie weszło do polszczyzny. Wydaje się, że nastapiło to później, na co prawdopodobnie wskazują XVI-wieczne translacje tekstów łacińskich zawierających grę słów „culus”-,oculus”, które w polszczyźnie gry tej nie oddają. Przykładem może być choćby Marchołt w tłumaczeniu Jana z Koszyczek, gdzie wyraz „oko” na oznaczenie odbytu wcale się nie pojawia. W wersji polskiej mamy „oczy” i „pośladki” jako odpowiedniki łacińskich „oculis” i „culo”30. Sądzę zresztą, że przedstawione przez Grześkowiaka i Edera argumenty mocno osłabiają zasadność homoseksualnej propozycji rozwiązania. Należałoby więc sądzić, iż taka opcja (tj. tyłek męski jako rozwiązanie zagadki) to coś w rodzaju ,fałszywego przyjaciela”31: wszystko zdaje się pasować i odbiorca tak właśnie mógłby utwór odczytać, ale gruntowne prześledzenie kontekstu kulturowego pomaga wybrnąc ze ślepego zaułka.

Pozostaje jeszcze do omówienia jedna kwestia, mianowicie zwierzęcość rzyci. Nie jest ona zbyt zawiła, wszak o związkach obu bytów świadczą choćby Rejowe Figliki, w których czytelnik, „spoglądając” na wypięty kobiecy tyłek, widzi „puhacza” (zapisywanego jeszcze przez „h”, co pięknie uwydatnia etymologię tego słowa, wywodzącą się od dźwiękonaśladowczego leksemu „puhać” 〈 głosie wydawanym przez sowę $)$ ), „wyżliczkę” czy „ćwika” (= "tresowany ptak drapieżny, używany do polowania') ${ }^{32}$. Podobne nazewnictwo (czyli związane $\mathrm{z}$ określeniami zwierząt, choć innymi niż te w XVI stuleciu) jest zresztą wykorzystane również dzisiaj i dotyczy tak żeńskich, jak i męskich narządów płciowych ${ }^{33}$. O „zwierzęcej naturze” żeńskiego narządu płciowego wspominają w swych pracach zresztą także moi poprzednicy, więc poprzestanę na takim krótkim uzupełnieniu owego wątku.

Zob. ibidem, s. 179: „sonet o pierdzie potwierdza językowe wyrażenie znane hiszpańszczyźnie i francuszczyźnie, polszczyźnie zaś w małym stopniu. "Klucze" po polsku wchodzą w "dziurkę", która lokalnym erotomanom na ogół konkretyzuje się jako wagina, ale nic nie stoi na przeszkodzie w wyobrażaniu sobie odbytu; lecz po hiszpańsku wchodzą w "oko", co wywołuje wyrażenie "ojo del culo" ("dziurka w dupie", "odbyt", "zwieracz") i stąd u Quevedo pierd to "głos z oczka", "la voz del ojo". Dodatkowo za taką interpretacją oka przemawiają według S o b ol c zy k a (ibidem, przypis 29) utwory innego poety, Góngory: „W kontekstach zawsze homoerotycznych [oko] występuje także w [...] przypisywanym Góngorze wierszu A un puto ("está que le llena el ojo" - "wchodzi / wsadza mu w oko") czy w satyrycznym wierszu o sodomicznej relacji między włoskim zakonnikiem i hiszpańskim kawalerem, opowiedzianej z perspektywy damy Hiszpana, napisanej przez brata Damiána Cornejo, który kończy się dwuwersem: "que al fin le llenaste el ojo, / y temo que te le llene", co oznacza (mówi kochanka Hiszpana) "że w końcu wsadziłeś / wypełniłeś mu oko // i boję się, że teraz on ci wsadzi / wypełni"”. Rozmowy Salomona z Marchołtem, s. 116. Zob. też E d e r, op. cit., s. 29.

31 Mam na myśli fenomen tzw. false friend, gdzie para słów lub wyrażeń brzmi w dwóch językach tak samo lub podobnie, ale ma inne znaczenia.

32 W omawianym zbiorze podobne nazewnictwo występuje także w odniesieniu do męskich narządów płciowych. Przykładem może być pies myśliwski, „wyga” (z figlika Pani, co wyżliczki dać nie chciaŁa), „konik” (Baba, co ćwika przedawała) czy fantastyczne „smoki” (z utworu Nowiny o smokach). Ostatnio nawet byliśmy świadkami „odrodzenia” Rejowego „puhacza”, który w nurcie kultury popularnej (na internetowej platformie YouTube) zmaterializował się w postaci „sowy” oraz hasła: „poka sowę", będącego tytułem (niestety wątpliwej wartości artystycznej) utworu muzycznego wykonywanego przez A. Bogusz (znaną jako SexMasterka). Hasło „poka sowę” doczekało się nawet derywatu od niego utworzonego, nawiązującego do słowa „pokazywać” - „pokasować” (= "pokazywać sowę, tj. piczę). 
W środowisku badaczy była też omawiana (choć niepublikowana) kwestia, czy za „Źwierzęciem” Kochanowskiego nie skrywa się członek męski. W tym wypadku przede wszystkim jednooczność stanowi cechę, która naprowadza na takie rozwiązanie. Do dziś znane sa (i to nie tylko w języku polskim) określenia w rodzaju ,jednooki wąż”, ,jednooki król”, ,jednooki potwór”, a nawet... ,jednooki mleczarz" ${ }^{34}$, które żartobliwie opisują tę część męskiego ciała ${ }^{35}$. Podobne określenia funkcjonują szczególnie mocno zwłaszcza w potocznej odmianie języka. Poza tym członek (w przeciwieństwie do żeńskiego organu płciowego) bez wątpienia może „stać w kroku”. Zgodnie z definicją czasownika „stać”, opracowaną przez Krystynę Wilczewską dla Stownika polszczyzny XVI wieku na podstawie obszernego materiału leksykograficznego (ponad 4300 kartek redakcyjnych), słowo to oznacza przede wszystkim 'utrzymywać się nieruchomo w pozycji pionowej'. Ponadto, w obrębie sensu podstawowego omawianego leksemu autorka wydzieliła jeszcze podznaczenie, które wskazuje na konkretny podmiot, będący wykonawcą czynności wyrażonej przez czasownik: „o człowieku i zwierzęciu: stać = nie siedzieć i nie leżeć, w pozycji pionowej wspierać się na nogach; w takiej pozycji znajdować się gdzieś"36. I ten sens Wilczewska jeszcze zawęziła, doprecyzowując ostateczne znaczenie. Otóż stać mogą takie obiekty pionowe, których wierzchołek sięga ponad ich podstawę (albo otoczenie). Od razu widać, że definicja ta nie służy opisowi ani waginy, ani rzyci. Żadna z nich bowiem nie przyjmuje „pozycji pionowej”, ani też „w takiej pozycji nie zajmuje jakiegoś miejsca”, w dodatku „wierzchołkiem sięgając ponad otoczenie”. Co więcej, we fraszce sposób stania zwierzęcia został skonkretyzowany. Zobrazowane przez Kochanowskiego stworzenie „stoi w kroku”. W polszczyźnie XVI wieku zwrot ten należy odczytywać przede wszystkim jako 'stać w rozkroku, stać na rozstawionych (= rozkraczonych) nogach', to jest: 'przyjąć pozycję bojową, pozycję gotowości do ataku'37, co bardziej pasuje do penisa, któremu przypisuje się rolę aktywną w miłosnym akcie, w przeciwieństwie do pasywnej waginy (albo rzyci). Najistotniejsze dla naszych rozważań pozostaje wszakże to, że słowa „stać” użył Kochanowski w zupełnie zrozumiałej i jednoznacznej fraszce o tematyce erotycznej Do Petryła, w której zabawa $\mathrm{z}$ czytelnikiem polega na polisemicznym wykorzystaniu interesującego nas czasownika:

Dawnoć nie stoi owa rzecz, Petryło,

A przedsięć igrać z niewiastami miło.

Zob. na stronie: http://www.nauklove.pl/popeye-little-bob-jednooki-mleczarz-rozne-imiona-penisa/ (data dostępu: 10 IX 2018).

35 W materiałach SpXVI nie ma jednak tekstów, które ukazywałyby ten narząd w taki sposób. Nie brak oczywiście słów go prezentujących, jak choćby np. „mądzie”, pojawiające się i u J. Kochanowskiego we fraszce $O$ proporcyjej, czy ogólne określenie „męskie stroje”, nie brak także metaforycznych sformułowań (wspomniane przez Edera „wiosło”, którym bohater fraszki O flisie, „ku paniej godzi” 〈KF s. 134〉), a nawet metafor związanych ze zwierzętami („smok” bądź „wyżeł” w Figlikach Reja), ale jednookiej bestii nie ma.

36 Zatem przyjęta przez moich poprzedników definicja tego czasownika (jako 'znajdować się, być gdzieś umiejscowionym') okazuje się nieprecyzyjna, niepełna dla tego przypadku. Jest ona możliwa dla obiektów innego typu, ale nie dla ludzi czy zwierząt (a w Gadce podmiotem jest właśnie coś, co autor - dosłownie lub metaforycznie - uznaje za „Źwierzę”). Materiał SpXVI to poświadcza, ale i współcześnie dla czasownika tego żaden słownik nie notuje wspomnianego znaczenia.

37 Zob. Ł. Górnick i, Dworzanin polski. Kraków 1566, k. Fv: „takież i szermierz, jako rychło broń w rękę weźmie, a w kroku stanie, tak wnet poznać jeśli co umie”. Zob. też ibidem, k. 18v. 
Wyjadłeś wszytki recepty z apteki,

Dla tej ociętnej i niestałej deki.

Wielka część ludzi nie będzie wierzyła,

Że co nie stojąc, przedsię stoi siła. [KF s. 45$]^{38}$

Nikt chyba nie ma watpliwości, o czym jest mowa w utworze i jaka to „rzecz” „nie stoi”, i to od pewnego już czasu, mimo wysiłków (a raczej: wydatków) jej posiadacza. Stoi (we Fraszkach Kochanowskiego) członek męski i poeta mówi o tym wprost. Dlatego też waginę, a nawet utożsamianą z nią rzyć - jako ostateczne rozwiązanie zagadki - należy odrzucić. Gdyż żadna z nich nie stoi, bo stać najzwyczajniej w świecie nie może. Owa cecha bardziej odpowiada męskiemu organowi płciowemu, podobnie zreszta jak jednooczność. Wszakże podążanie i tym tropem wiedzie czytelnika na manowce. Cóż bowiem z tego, że dwie cechy: jednooczność i zdolność do stania, wskazują na penis, skoro inne elementy opisu nie pasuja już zupełnie: ponieważ bez wątpienia ani nie wydaje on głosu piorunowego, ani nikt do niego żadnym (ślepym czy też nie) bełtem nie strzela, wręcz przeciwnie. Zwrócił na to uwagę Grześkowiak, podający w swym tekście przykłady wierszy, w których stosunek seksualny jest przedstawiony za pomoca metafory polowania. I to członek bywa w tego rodzaju twórczości bełtem, nigdy zaś celem. Podobnie i u Kochanowskiego, nawet $\mathrm{w}$ cytowanej fraszce II 11 , będącej kpiną $\mathrm{z}$ impotenta. Penis został tutaj określony jako „deka”, a zatem 'sztylet - broń ostra, mogąca zadawać ciosy' (oczywiście, w odniesieniu do bohatera owej fraszki słowa tego użyto w sposób prześmiewczy, ironiczny). Co jeszcze dyskwalifikuje fallusa w kontekście czarnoleskiej zagadki? Otóż choć potrafi on stać, to niewątpliwie nie czyni tego „zawżdy” (= 'zawsze'), ale tylko w pewnych warunkach i przez określony czas. A więc i tę fundamentalną, wydawałoby się, cechę "korzenia męskiego"39 Gadka podważa, bo opisuje przedmiot, który „stoi w kroku” stale, nie tylko okazjonalnie.

Jak zatem widzimy: rzecz nie jest wcale taka oczywista. Nie możemy być pewni, że Gadka ma rozwiązanie nieobyczajne, odnoszace się do konkretnego desygnatu, jaki stanowi żeński czy męski organ płciowy, a nawet (szeroko pojmowana) - rzyć. Żaden $\mathrm{z}$ tych bytów nie spełnia bowiem wszystkich wymogów, stawianych przez tekst, w sposób nie budzący absolutnie żadnych wątpliwości.

A może jednak Gadka ma rozwiązanie obyczajne? Albo wchodzi w grę i jedno, i drugie? To, że istniały zagadki o wydźwięku (na pierwszy rzut oka czy - ucha) nieprzyzwoitym, ale $z$ ukrytym drugim, przyzwoitym dnem, jest udokumentowane ${ }^{40}$. Pro-

Pracami wciąż bezkonkurencyjnymi są te autorstwa toruńskiego badacza zagadki, J. M. Ka sjan a: Poetyka polskiej zagadki ludowej. Toruń 1976; Polska zagadka ludowa. Wrocław 1983; Usta i pióro. Studia o literaturze ustnej i pisanej. Toruń 1994. Zob. też Zagadki rozmaite i pytania stużace zabawie i nauce. Antologia polskiej zagadki literackiej. Wstęp, przypisy J. M. Ka s j a n. Toruń 1994.

Zob. też fraszkę Do dziewki (KF s. 131-132), gdzie stary dąb, który „stoi potężnie, bo ma korzeń zdrowy", symbolizuje potencję mężczyzny będącego już w pewnym wieku.

To wdzięczne określenie męskiego członka pojawia się w tekstach z XVI wieku wiele razy. Zob. Z. Chyła-Bełk ot, Korzeń. Hasło w: Słownik polszczyzny XVI wieku, t. 10 (Red. M. R. May e n o w a. Warszawa 1976). Zob. też na stronie: http://spxvi.edu.pl/indeks/haslo/59139\#znaczey en ow a. Warszawa 1976). Zob. też

http://rcin.org.pl 
blemem do rozstrzygnięcia pozostaje określenie cezury czasowej owej dwuznaczności. Grześkowiak stwierdza, iż dzieje się to w XVII stuleciu, kiedy „strategia zastępczej deskrypcji aktu płciowego okrzepła [...]" ${ }^{41}$. Wydaje się, że dwuznaczność rzeczywiście w XVII wieku niewatpliwie istniejąca, mogła się pojawić jednak już wcześniej, czego przykład stanowi choćby taka oto gadka z Historyj rzymskich:

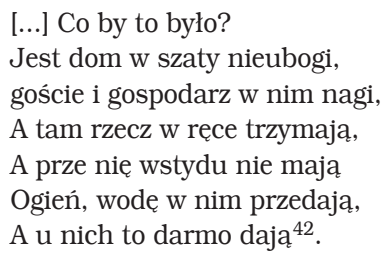

W zagadce tej występuje kilka elementów, które można uznać za dwuznaczne, bo odsyłaja one do wyobraźni erotycznej człowieka: nagość gospodarza i przebywających tam ludzi, tajemnicza „rzecz”, która „w ręce trzymaja” czy brak wstydu wszystkich zebranych $\mathrm{w}$ tym miejscu. Współcześni odbiorcy dostrzegają w tym utworze raczej obraz domu publicznego niż łaźni, która stanowi właściwą odpowiedź:

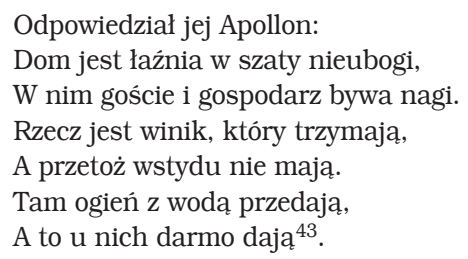

Jak więc widać, nieobyczajna z pozoru gadka może mieć niewinne rozwiązanie. $Z$ łaźni żartował sobie zresztą i Kochanowski, który dostrzegał ambiwalentny charakter tego locum: $z$ jednej strony, ludzie przychodzą tam, by oczyścić swe ciało, $\mathrm{z}$ drugiej - stanowi ona miejsce stwarzające okazję do grzechu cielesnego, rozbudzające wyobraźnię erotyczną. W interesującym nas kontekście łaźnia pojawia się we fraszce $O$ Gospodyniej. Jej bohaterka jest roztropna niewiasta, która odprawia natrętnego adoratora w osobliwy sposób:

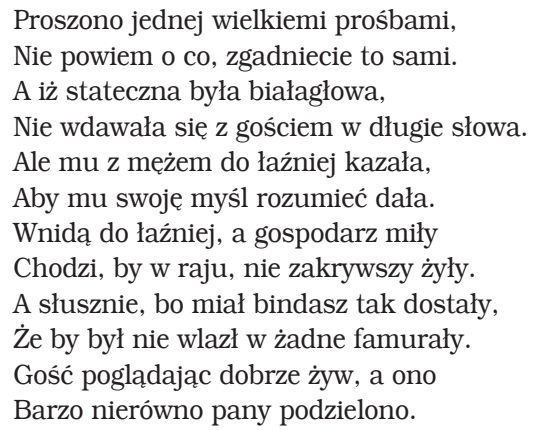


Nie mył się długo i jechał tym chutniej,

Nie każdy weźmie po Bekwarku lutniej. [KF s. 23]

W innej fraszce, O łaziebnikach, poeta zawarł paralelę między „łaziebnikami” a „kurwami”:

Łaziebnicy a kurwy jednym kształtem żyją,

$\mathrm{W}$ tejże wannie i złego, i dobrego myją. [KF s. 113]

Również dwuznacznie (jako przestrzeń flirtu) Kochanowski ukazał łaźnię jeszcze we fraszce $O$ Kachnie:

Kachna się każe w łaźni przypatrować,

Jeślibych ją chciał nago wymalować:

A ja powiadam, gdzie nas dwoje siędzie,

Tam pewna łaźnia, mówię, łaźnia, będzie. [KF s. 15-16]

Dwuznaczność, aluzyjność, przedstawianie jednej rzeczy za pośrednictwem innej - zatem nie tylko dotyczy Gadki, lecz stanowi cechę pewnej grupy tekstów Kochanowskiego, zwłaszcza tych o tematyce erotycznej czy skatologicznej. A jednak Gadka różni się od nich. Eder i Grześkowiak „nieprzyzwoite” utwory czarnoleskiego poety wpisali w szeroki kontekst dzieł o podobnej tematyce oraz sposobie obrazowania, żeby pokazać, że i Gadka mieści się w ich orbicie. Ale tak nie jest. Wszystkie bowiem utwory Kochanowskiego przynależące do grupy erotyczno-skatologicznej, także te najbardziej frywolne, jak fraszka O flisie czy Na miernika, w rzeczywistości nazywają rzeczy po imieniu, a więc tak, że nawet jeśli poeta używa aluzji, podmienia słowa czy litery ${ }^{44}$, to od razu wiadomo, o co chodzi. Omawiane utwory sa dwuznaczne tylko pozornie, Gadka - nie. To również pozwala przypuszczać, że należy szukać innego jej rozwiązania.

Jeśli więc przyjąć, że Gadka ma obyczajne rozwiązanie, to może warto przyjrzeć się już istniejącym propozycjom takiej właśnie jej interpretacji. Krzyżanowski, a za nim Pelc, również zasłużony w badaniach nad twórczością Kochanowskiego, twierdzili, iż także broń palna może być uznana za - jeśli nie jedyne, to przynajmniej równorzędne, obok obscenicznego, rozwikłanie czarnoleskiej enigmy. Krzyżanowski sądził, że rozwiązaniem Gadki jest lufa muszkietu opartego na widłach lub armata na lawecie, przy czym zwrócił uwagę na ewentualność dwuznacznego odczytania utworu: „Dowcip zagadki polega na jej dwuznacznym rozwiązaniu: na pierwszy rzut oka chodzi tu o zadek, naprawdę o broń palną"45.

W Szkicach folklorystycznych badacz sprecyzował swoje stanowisko dokładniej i tak to opisał:

Wprowadzenie w zagadkach dworskich przedmiotów wstydliwych, przesłanianych dowcipnym ich ujęciem, pozwala przypuścić, iż dwory bawiły się również zagadkami dwuznacznymi, których dowcip polegał na podwójnym rozwiązaniu, pierwszym i niemal oczywistym, ale nieprzystojnym, i drugim przyzwoitym, ale daleko trudniejszym do odgadnięcia. Klasyczny i chyba najdawniejszy przykład zastosowania tej sztuczki to Gadka Kochanowskiego. Jako ro z w i ą z a n i e o d r u c how e nasuwa się 
tutaj wyraz „tyłek”, jako rozwiązanie dalsze, wymagające dzisiaj znajomości dawnej techniki wojennej, wyraz "muszkiet”, ciężka broń palna, zktórej strzelano po umieszczeniu jej na specjalnej podporze, widłach ${ }^{46}$.

Zauważmy, że uczony niczego nie stwierdza na pewno, ale raczej snuje przypuszczenia. Podobną ostrożność zachowywał zresztą także Przyborowski, od którego Krzyżanowski zaczerpnął swój pomysł. Nie wypowiadając się szerzej, ani nie wgłębiając się w szczegóły, w Wydaniu Pomnikowym dzieł poety warszawski uczony stwierdził tylko: „m o ż e działo umieszczone na lawecie” 47 . Tropem tym podąży jeszcze Pelc. Przywołuje on swego poprzednika, wymieniając jego nazwisko, przy czym raczej skłania się ku temu, by za rozwiązanie uważać armatę: „J. Krzyżanowski bardziej ukrytego sensu szuka w muszkiecie, opieranym na widłach, lub w armacie osadzonej na lawecie (jeśli już, to raczej to drugie!)" 48 .

Jako że Pelcowi znany był jeszcze jeden wykład Gadki, pochodzący od Pankowskiego, który z kolei zaproponował, iż to tyłek homoseksualisty jest tu odpowiedzią ${ }^{49}$, musiał się badacz jakoś i do tego odnieść. Ostatecznie interpretacja Pelca przyjmuje możliwość współistnienia dwóch rozwiązań: obscenicznego (tyłek, ale mężczyzny) i obyczajnego (raczej działo niż muszkiet).

Jak zatem widać, Gadka nastręczała problemów interpretacyjnych także badaczom starszego pokolenia, uznawanym dziś za klasyków w swej dziedzinie. Moją uwagę przykuło to, jak dawniejsi historycy literatury wypowiadają się o tym tekście. Unikają oni, w opozycji do tych młodszych, swoiście radykalnych rozstrzygnięć. Ani Pelc, ani jego poprzednicy nie przedstawiaja jakiegoś jednego, jedynie słusznego rozwiązania. Dostrzegamy to już w toku wywodu, gdzie bardzo często posługują się oni stwierdzeniami w rodzaju: „może”, „pozwala przypuścić”, ,jeśli już”. Myślę, że było to podyktowane nie tylko pruderią czy zakłopotaniem w zetknięciu z niejednoznaczną treścią utworu, na którego temat musieli oni przecież wyrazić swoje zdanie, ale i intuicją, każącą badaczowi unikać zbyt łatwych odpowiedzi, takich, które nasuwają się niejako natychmiast i są najbardziej oczywiste i najprostsze. Dlatego zdecydowałam się pochylić raz jeszcze nad tymi „przyzwoitymi” propozycjami rozwiązań, przez dzisiejszych badaczy odrzucanymi nieomal od razu, jako nie wytrzymujące naukowego, a raczej - interpretacyjnego probierza. Czy jednak taka postawa jest do końca słuszna? Czy rzeczywiście nie można jakoś sensownie połączyć opisywanego jednookiego „Źwierza” z armatą bądź lufą muszkietu?

Moim zdaniem, da się to uczynić. W związku $z$ tym postanowiłam rozwinąć myśl Krzyżanowskiego i Pelca, którzy ograniczyli się tylko do zdawkowych wypo-

46 i zagadki. - Z zagadnień przysłowioznawstwa. Kraków 1980, s. 28-29. Zob. też J. Kr zyża n ows ki, Zagadka. Hasło w: Słownik folkloru polskiego. Red. J. Krzy ża now s ki. Warszawa 1965, s. 453.

47 J. Ko c ha n ow s ki, Gadka. W: Dzieła wszystkie. Wyd. Pomnikowe. T. 2. Warszawa 1884, s. 434, przypis 1.

48 J. Kochanowski, Fraszki. Oprac. J. Pelc. Wyd. 2, zmien. Wrocław 1991, s. 155, przypis. BN I 163.

49 M. Pa nkow ski, Polska poezja nieokrzesana (próba określenia zjawiska). „Teksty” 1978, nr 4, s. 45. Zob. też wypowiedź tego autora w książce K. Bi el a s Niesformatowani. Rozmowy (Kraków 2007, s. 282-283). 
wiedzi i nie przedstawili jakiegoś obszerniejszego, a tym samym spójnego i konkretnego, uzasadnienia swoich stwierdzeń, nie dokonali dokładnej interpretacji ani rozbioru omawianej fraszki, poprzestając na propozycjach, które pozostawili otwarte. Uważam jednak, iż owe propozycje nie były chybione. Stwarzają bowiem możliwość powiązania Gadki z określonym momentem biografii poety, przypadającym na lata 1567-1568, kiedy Kochanowski wedle wszelkiego prawdopodobieństwa towarzyszył królowi Zygmuntowi Augustowi podczas tzw. wyprawy radoszkowic$k^{k i e j}{ }^{50}$. Wiadomo zreszta, że nie był to jedyny wojskowy epizod Jana z Czarnolasu. Pelc, zwolennik militarnego rozwiązania Gadki, zasugerował, iż wtajemniczenie żołnierskie poety mogło nastapić i wcześniej, już w 1557 roku. To całkiem prawdopodobne, że Kochanowski uczestniczył wtedy w wyprawie inflanckiej, zorganizowanej przez Zygmunta Augusta i zakończonej ugoda w Poswolu ${ }^{51}$. Wyprawa ta okazała się w istocie wojskową demonstracją. Król Polski Zygmunt II August zagroził kawalerom mieczowym, którzy wypowiedzieli posłuszeństwo Litwie i Polsce i zobowiązali się do płacenia trybutu Rosji, interwencją zbrojną. We wrześniu $1557 \mathrm{w}$ obozie pod Poswolem zgromadził 26 tys. żołnierzy i 56 armat wojska litewskiego pod komendą hetmana wielkiego litewskiego Mikołaja Radziwiłła Rudego i 20 tys. wojsk polskich dowodzonych przez Jana Mieleckiego ${ }^{52}$. Inne źródła wspominaja jednak, że liczebność zjednoczonych armii Polski i Litwy dochodziła do 100 tys. zbrojnych ${ }^{53}$, wśród których odznaczał się szczególnie oddział rycerzy tzw. zaciężnych, armat zaś było aż 68 , nie brakowało też piechoty wyposażonej w broń palną ${ }^{54}$.

Demonstracja zbrojna wywarła spodziewane wrażenie na zakonnikach inflanckich: 14 IX wielki mistrz Johann Wilhelm von Fürstenberg ukorzył się przed Zygmuntem Augustem i podpisał sojusz skierowany przeciwko Rosji. Pelc przychyla się również do opinii, że i w kolejnym przedsięwzięciu organizowanym przez Zygmunta II, we wspomnianej wyprawie radoszkowickiej, poeta brał zapewne udział. Była to kampania zorganizowana $z$ nie mniejszym rozmachem niż poswolska.

W lutym 1567 Rosja zawarła ze Szwecja przymierze skierowane przeciwko Litwie. Zygmunt August postanowił wówczas przeprowadzić akcje zbrojną, licząc na wywołanie w Rosji powstania kniaziów i bojarów. Na przełomie 1567 i 1568 roku, pod Radoszkowiczami, niedaleko Mińska, zebrało się 47 tys. żołnierzy, z czego 30 tys. pospolitego ruszenia oraz 2400 posiłkowych żołnierzy Korony z około 100 armatami. Działania owych wojsk nie uznaje się jednak za faktyczny atak, ale za pokaz siły. Zgromadzeni w obozie królewskim rycerze nie tyle prowadzili walkę, ile występowali jako harcownicy, prezentowali swoje umiejętności oraz uzbrojenie, by

O udziale Kochanowskiego w tej wyprawie wspomina W. U rban (Poznań skarbnica materiałów do Kochanowskiego. „Pamiętnik Biblioteki Kórnickiej” 1981, z. 17, s. 146-147).

51 Zob. J. Pelc, Kochanowski a wyprawa inflancka $w$ roku 1557. (I jeszcze o „przypasanym do miecza rycerzu”. „Odrodzenie i Reformacja w Polsce” 1992.

52 Zob. S. Ka rw ow s ki, Wcielenie Inflant do Litwy i Polski 1558-1561. Poznań 1873.

53 Zob. T. Narbutt, Dzieje narodu litewskiego. T. 9. Wilno 1841, s. 312-314. - F. Ko n e czny, Dzieje Polski za Jagiellonów. Kraków 1903.

54 Zob. H. Ko ta r s ki, Wojsko polsko-litewskie podczas wojny inflanckiej 1576-1582, sprawy organizacyjne. „Studia i Materiały do Historii Wojskowości” t. 18 (1972), cz. 1, s. 97. - J. W i m m er, Historia piechoty polskiej. Do roku 1864. Warszawa 1978, s. 144. 
w ten sposób zniechęcić wroga. Miał także wówczas miejsce tzw. popis, a więc spis żołnierzy ${ }^{55}$.

Co jest szczególne interesujące i istotne dla naszych rozważań, to fakt, iż obie wyprawy, w których czarnoleski poeta prawdopodobnie brał udział, skończyły się podobnie: bezkrwawo, do starcia między przeciwnikami nie doszło, obecność zaś polskich rycerzy ograniczyła się do pokazu siły zjednoczonych Korony i Litwy. Stwarzało to dobre warunki dla Kochanowskiego, który, przebywając w obozie wojskowym mógł dobrze przyjrzeć się panującym tam obyczajom, a także zapoznać się $\mathrm{z}$ bronia.

Wszystkie te wydarzenia oddziaływały na autora Gadki i każde $\mathrm{z}$ nich jakoś upamiętnił on w swojej twórczości. Pelc wylicza teksty, które miały związek z wyprawą inflancką ${ }^{56}$ :

W biografii i w twórczości Jana Kochanowskiego wśród licznych zagadek jedna dotyczy związów młodego wówczas twórcy z wyprawą inflancką Zygmunta Augusta w roku 1557, zakończoną we wrześniu tegoż roku pokojem w Poswolu, co otwierało drogę do późniejszych działań, zmierzających do włączenia Inflant $w$ orbitę krajów podległych władzy ostatniego $z$ Jagiellonów. Właściwie jedynym pewnym świadectwem pozwalającym nam wiązać młodego Kochanowskiego z tą wyprawa jest jego Elegia II z Księgi drugiej według wczesnej redakcji w Ioannis Cochanovii Elegiarum libri duo, znanej z zapisu w sylwie Jana Osmolskiego. Potem po pewnych zmianach w późniejszej redakcji w Elegiarum libri IIII utwór ów był Elegia VII w tejże Księdze drugiej. Redakcja wczesna zbioru Elegiarum libri duo, znana nam tylko $z$ dawnego rękopisu, zapewne nie drukowana, powstała nie później niż w latach 1559-1561, a raczej nie później niż w latach 1559-1560, niektóre utwory wchodzace do tejże redakcji cyklu powstały zresztą niewątpliwie wcześniej. Redakcja późniejsza znana nam jest z wydania odbitego w roku $1584 \mathrm{w}$ Krakowie w dwu wariantach druku pod prasami oficyny Jana Januszowskiego. Powstawała ona niewątpliwie podczas wielu lat, począwszy od lat sześćdziesiątych aż po osiemdziesiąte XVI stulecia.

W obu, niezbyt zresztą różniących się wersjach wspomnianego utworu, będącego najpierw Elegia II w Księdze drugiej, a potem Elegia VII tejże księgi, Jan Kochanowski opiewał tryumf zwycięsko zakończonej wyprawy inflanckiej Zygmunta Augusta w roku 1557. W utworze tym uderza wręcz, zwłaszcza w jego wersji wczesnej, że jest to tekst związany bezpośrednio z zakończeniem wyprawy i zawarciem 14 września 1557 r. traktatu w Poswolu wieńczącego tryumf królewski [... $]^{57}$.

Badacz swoją argumentację, zakładającą czynny udział poety we wspomnianym wydarzeniu, opiera m.in. na tym, iż Kochanowskiego (od młodości) łączyły więzy przyjaźni z Mikołajem Mieleckim ${ }^{58}$, jednym $z$ ważniejszych uczestników tejże wyprawy. Pelc sugeruje, że to być może właśnie za sprawą Mieleckiego znalazł się Kochanowski w żołnierskim obozie. Wiadomo, iż ich przyjaźń okazała się trwała, gdyż poeta poświęcił Mieleckiemu także kilka późniejszych utworów z Fraszek:

Zob. J. N a t a n s o n - Le s k i, Dzieje granicy wschodniej Rzeczypospolitej. Cz. 1: Granica moskiewska w epoce jagiellońskiej. Lwów-Warszawa 1922, s. 168-170. - K. Pi w a r s k i, Niedoszła wyprawa tzw. radoszkowicka Zygmunta Augusta na Moskwę. (Rok 1567-1568). „Ateneum Wileńskie” 1927, nr 13, s. 256-286. - S. Bodniak, Najdawniejszy plan porozumienia Polski z Moskwa przeciw Niemcom. „Pamiętnik Biblioteki Kórnickiej” 1947, s. 77-78. Zob. też Na rb u t, op. cit., s. $432-433$.

56 Zob. S. Kot, Jana Kochanowskiego podróże i studia zagraniczne. W zb.: Studia staropolskie. Księga ku czci Aleksandra Brücknera. Kraków 1928, s. 403. Na tę pracę powołuje się Pelc i rozwija postawioną przez Kota tezę, iż Kochanowski mógł być naocznym świadkiem wyprawy inflanckiej. Pelc, op. cit., s. 89-90.

58 Towarzyszył on w wyprawie swemu ojcu, Janowi Mieleckiemu, który był jednym z dowódców (zob. ibidem, s. 92). 
Przyjaźń z Mikołajem Mieleckim zachował Jan Kochanowski nie tylko w latach pięćdziesiątych XVI w. O tym świadczą Fraszki. Kiedy w latach sześćdziesiątych Mikołaj Mielecki starał się o rękę Elżbiety Radziwiłłówny, córki Mikołaja Czarnego, Kochanowski udającego się w konkury, a raczej może już na ślub, który odbył się 12 września 1566 r., obdarował kilkoma przyjacielskimi wierszykami, o czym w jednym zapewne $z$ nich, będącym fraszką 45 Ksiag pierwszych, pisał serdecznie. Drugim świadectwem przyjaźni, a zarazem i godności ubogiego poety wobec syna możnego pana, młodego wojewodzica od roku 1557 będącego już starostą, była fraszka 99 Ksiag wtórych, podobnie jak poprzednia adresowana Do Mikołaja Mieleckiego ${ }^{59}$.

Zbieżne obserwacje przedstawia Jakub Niedźwiedź, który również odnotowuje, iż Kochanowski pozostawiał ślady poetyckie związane $\mathrm{z}$ działaniami wojennymi królów polskich - wpierw Zygmunta II, a potem Stefana Batorego:

O wojnach moskiewskich Kochanowski pisał kilkakrotnie; najwcześniejsze wiersze należące do tej grupy pochodzą prawdopodobnie z 1567 roku: elegia otwierająca księgę trzecią z Elegiarum libri IV i pieśń 13 z Pieśni ksiag pierwszych. Oba powstały w związku z koncentracją armii litewsko-polskiej pod Radoszkowiczami niedaleko Mińska latem i jesienią 1567 roku. Jak się przypuszcza, Kochanowski jako sekretarz w kancelarii Zygmunta Augusta brał udział w tej wyprawie („straż dzierżem niecąc ognie aż do rana", P I 13, 4). Jednak wojny prowadzone przez Stefana Batorego okazały się bardziej inspirujące niż zmagania $z$ czasów pierwszej wojny północnej. Wszystkie trzy kampanie batoriańskie $\mathrm{z}$ lat 1579, 1580 i 1581-1582 znalazły odbicie w utworach polskich i łacińskich Kochanowskiego. W 1579 roku wyszła wspomniana już polska Pieśń o zdobyciu Połocka oraz Ode de expugnatione Polottei, w 1583 roku Jezda do Moskwy, w której poeta przedstawiał kawaleryjski zagon oddziałów Krzysztofa Radziwiłła „Pioruna” w głębi państwa moskiewskiego, i wreszcie było też łacińskie Epinicion opiewające Stefana Batorego, które zostało odśpiewane przez Krzysztofa Klabona na weselu Jana Zamoyskiego i Gryzeldy Batorówny w 1583 roku. Odwołania do zmagań z Moskwą pojawiają się w tle kilku innych utworów, m.in. epitalamiach dla Krzysztofa Radziwiłła „Pioruna” (1578) i Jana Zamoyskiego (1583) oraz - jak się przypuszcza - w zakończeniu Odprawy posłów greckich (1578) ${ }^{60}$.

W kampaniach organizowanych przez Stefana Batorego poeta nie brał już z pewnością czynnego udziału, ale, jak zaświadcza Niedźwiedź, przygotowywał utwory propagandowe, mające zachęcić do uczestnictwa w tych bojach, wzmocnić zaufanie do osoby króla oraz wiarę w zwycięstwo. Wiadomo też, że Kochanowski znał osobiście uczestników wyprawy na Moskwę i z nimi rozmawiał ${ }^{61}$.

Epizod wojskowy upamiętnił poeta we fraszce Do gór i lasów, która, podobnie jak Gadka, pochodzi również z trzecich ksiąg zbioru. Jest utworem autotematycznym i rzeczywiście odzwierciedla - na swój liryczny sposób - biografię Kochanowskiego, opisuje rozliczne funkcje przezeń sprawowane, role, w które się on wcielał, niczym zmiennokształtny Proteus. Jedna z postaci owego Proteusa to żołnierz:

Dziś żak spokojny, jutro przy pas any

Do miecza rycerz: dziś między dworzany

[. . . . . . . . . . . . . ]

Taki był Proteus, mieniąc się to w smoka,

To w deszcz, to w ogień, to w barwę obłoka. [KF s. 90-91]

Pelc uznał, że słowa te wolno odnosić do którejś z wojennych przygód Kocha-

Ibidem, s. 101

J. N i e dź wi e dź, Źródła, konteksty i okoliczności powstania „Ody o zdobyciu Połocka” Jana Kochanowskiego. „Terminus” 2016, z. 4, s. 363-364.

Zob. ibidem, s. 377. 
nowskiego, a nawet zasugerował (choć ze zwykłą sobie ostrożnościa), że owo „przypasanie do miecza” mogło nastąpić już w czasie wyprawy w 1557 roku, jeśli przyjąć, że poeta w niej uczestniczył. W trzeciej księdze cyklu znajduje się (poza Gadka oraz Do gór i lasów) także utwór Do fraszek, w którym autor konstatuje: ,ja wszytki [we fraszki] kładę tajemnice swoje” (KF s. 107). Zatem Fraszki miałyby stanowić klucz do tajemnic życia poety, odsłaniać koleje jego losu. Słowa te podchwycił Jacek Sokolski, współczesny badacz spuścizny czarnoleskiej ${ }^{62}$, który uważa, że w cykl owych niepozornych, wydałoby się, wierszyków, autor Gadki wpisał cały swój życiorys, a nawet go zakodował, co można odczytać za pomoca skomplikowanych operacji, przypominających liczbowy labirynt. Koncepcji tej wrocławski uczony poświęcił książkę Lipa, Chiron i labirynt: esej o „Fraszkach”63. Jeśli więc wierzyć temu, co przekazał poeta w wymienionych tekstach, i przyjąc eksperymentalno-hipotetyczny sposób badania jego biografii tak, jak robił to wcześniej Pelc, potem zaś w swej pracy Sokolski, to nie będzie nadużyciem stwierdzenie, że tajemnicza zagadka Kochanowskiego ma, być może, związek z wojskowymi przygodami wieszcza.

Kiedy zatem przyjmiemy, iż Gadka w jakimś sensie łączy się z wyprawą inflancką lub radoszkowicką i z przebywaniem Kochanowskiego w wojskowym obozie czy też z usługami poetyckimi, jakie autor Fraszek oddawał królowi Batoremu, to propozycje „militarne” przedstawione przez Przyborowskiego, Krzyżanowskiego oraz Pelca przestają wyglądać na zgoła naiwne i nietrafione ${ }^{64}$.

Czy jednak rzeczywiście Gadka może mieć coś wspólnego z pobytem Kochanowskiego w wojsku? A jeśli tak, to co łączy zupełnie, wydawałoby się, niepoważna fraszkę $z$ ksiag trzecich $z$ tymi wszystkimi wzniosłymi polskimi i łacińskimi utworami, opiewającymi królów, wodzów i rycerzy polskich, które wymieniają Pelc albo Niedźwiedź? Na pierwszy rzut oka chyba tylko to, że i na wojnie się strzela, i w Gadce strzela się do zwierza. Jakieś skojarzenia z rzemiosłem Marsa może też wzbudzać głos piorunowy. Jednak Krzyżanowski, a za nim Pelc, mieli intuicję, nakazująca im w jednookim stworzeniu dopatrywać się lufy muszkietu lub straszliwej armaty. Jak więc pogodzić oba te porządki? Otóż skłaniam się ku przypuszczeniu, że Kochanowski, kiedy znalazł się w wojskowym obozie, był zafascynowany machinami wojskowymi, które $z$ pewnością widział po raz pierwszy w życiu w takiej liczbie (przypomnijmy: na wyprawę inflancką zabrano 56, a możliwe, że blisko 70 dział ${ }^{65}$, pod Radoszkowicze - 100 armat; do tego trzeba doliczyć jeszcze ręczną broń palna). Ani wyprawa poswolska, ani popis radoszkowicki nie miały charakteru otwartej

$\mathrm{Nb}$. w ostatnim czasie Sokolski jest członkiem zespołu opracowującego Dzieła wszystkie Kochanowskiego, gdzie występuje w roli recenzenta.

63 J. So kols ki, Lipa, Chiron i labirynt. Esej o „Fraszkach”. Wrocław 1998.

64 Pelc (op. cit., s. 102) wskazuje, z właściwą sobie ostrożnością, możliwość, iż wojskowy epizod pojawiający się we Fraszkach („do miecza przypasany rycerz”) oraz Pieśń XIII z ksiag pierwszych mogły być inspirowane wyprawą radoszkowicka, ale nie rozstrzyga, czy rzeczywiście tak było, bardziej przychylając się ku opinii, iż to wcześniejsza wyprawa inflancka (1557) uczyniła Kochanowskiego rycerzem.

65 Były wśród owych dział: 2 słowiki, 4 śpiewaki, 14 wężownic, 4 falkony, 12 falkonetów, 4 koty ogniste, 16 moździerzy i 12 małych działek (zob. A. F. Grabs ki [i in.], Zarys dziejów wojskowości polskiej do roku 1864. T. 1. Red. nauk. J. Sik or ski. Warszawa 1965, s. 312). 
walki. Żołnierze przebywali tam w całkiem komfortowych warunkach, do ich zadań zaś należało tylko czuwanie nad wojskowym dobytkiem. Bez wątpienia prowadzono też ćwiczenia i parady z rynsztunkiem. To właśnie wtedy mógł czarnoleski mistrz, zainspirowany widokiem wspaniałych armat i ręcznej broni palnej, stworzyć coś w rodzaju żołnierskiego (koszarowego?) dowcipu-zagadki, który na pierwszy rzut oka/ucha budziłby skojarzenia erotyczne, wszakże naprawdę odnosił się do obozowego arsenału. Kiedy bowiem dobrze wczytamy się w Gadkę, musimy przyznać, że „Źwierz” o jednym oku równie dobrze może być zadkiem ponętnej dziewczyny, jak i działem czy nawet muszkietem.

Przeanalizujmy przeto raz jeszcze Gadkę wers po wersie, lecz tym razem znów, jak w matematycznym zadaniu, zastosujmy operacje podstawienia i za rozwiązanie czarnoleskiego równania uznajmy straszliwą armatę.

\section{„Jest źwierzę o jednym oku"}

Ten wers nie budzi żadnych wątpliwości: armata to bez wątpienia twór jednooczny. Wylot armaty bywał rozmaicie nazywany, funkcjonował jako „oko”, „sztuka oczna” (albo „wylotowa”), chociaż mianowano go także „gęba”, w przypadku zaś moździerzy „trąbą”. Prócz oka w budowie działa można zresztą wyróżnić i inne elementy: głowę (to szczytowa część lufy armaty), odchodząca od niej szyję, ogon, szpony, a nawet uszy $^{66}$. Ma zatem armata niewatpliwie ciało. Jak się okazuje - jest też zwierzęciem. Machiny te nie tylko posiadały imiona, ale nadto wiązały się one $z$ nazwami gatunkowymi zwierząt ${ }^{67}$. Zwierzęce miano nosiła w zasadzie każda armata, co regulowały statuty wojskowe. To, żeby „każde działo, każda sztuka, własne przezwisko miało [...]”, łączyło się z wymiarem praktycznym: „aby się zawżdy w zamieszce wiedziało, co ktemu działu, [...] która skrzynia, które naczynie, ku któremu działu [...]"68. Przykłady takich nazw wymienia w Sprawie rycerskiej Marcin Bielski i wyjaśnia ich genezę, opisuje również sposób postępowania $\mathrm{z}$ armatami:

Działa ku strzelaniu bywają też rozmaite: jedny wielkie, drugie śrzednie, drugie małe. $Z$ wielkich tłuką mury albo parkany, zową je od swych znaków, jako na którym znamię stoi wylane, jeśli Jaszczorka na nim stoi wylana, tedy Jaszczorka zowa, jeśli Smok albo Lew, albo Łabędz, albo Bazyliszek, tedy je tak zowa od znamion. Ale pospolicie zową Kartany albo też Borzace, $z$ tych według okazania wagi na to uczynionej strzelają

Zob. J. J a k u b o w s ki, Nauka artyleryi. Zebrana z najpóźniejszych autorów, napisana dla pożytku korpusu Artyleryi Narodowej z rozkazu i nakładem Jego Królewskiej Mci. T. 1-3. Warszawa 1781-1783 (o armatach szczegółowo traktuje t. 1 tego dzieła 〈s. 101 n.), od s. 138 rozpoczyna się rozdział O podziale i częściach armat). Zob. też $\mathrm{P}$. Ho g r e w e, Teoryczna i praktyczna nauka żotnierskich rozmiarów, czyli Miernictwo wojenne [...]. Warszawa 1790, s. 240. - Oczny, oko. Hasła w: M. S. Li in d e, Słownik języka polskiego. T. 3. Lwów 1857, s. 442, 533. - Wylot. Hasło w: jw., t. 6 (1860), s. 524. - W. K w a ś n i e w i c z, 1000 słów o dawnej broni palnej. Warszawa 1987, s. 98-99. Zob. Z. S t e fa ń s k a, Próba ustalenia typów i nazw dziat artylerii polskiej XVI i XVII wieku. „Muzealnictwo Wojskowe" t. 1 (1959). - S. Ko bi els ki, Polska broń. Broń palna. Oprac. typograf. L. Pi ą ty. Wrocław 1975, s. 56-57. - K. Ło p a t e c ki, Ideowa wymowa ozdób armatnich z przeŁomu XVI i XVII wieku. W zb.: Nad społeczeństwem staropolskim. T. 1. Red. K. Łopatecki, W. Wa lczak. Białystok 2007.

S. Ła ski, Prace naukowe i dyplomatyczne [...]. Wilno 1864, s. 31. 
i waga podnoszą ku mierze, i spuszczaja, aby tam trafił, gdzie chcesz, takież nabijanie ma być pod miara według baczenia sprawy prochu, bo chca drudzy tak wiele sypać prochu, jako kula żelazna zaważy, ale to źle bywa, bo tym obyczajem starga prędko działo. Gdy tedy działo wielkie wypalisz, to jest wystrzelisz, masz je chłodzić czym chłodnym albo ziemią okładać, albo wodą oblewać, drudzy winem chłodzą na prędkiej strzelbie, aby go zarazem gorąco nie nabijał, bo by się tak przez to zwątliło, trzeba też kulę dobrze obesłać w dziele, sianem albo mchem, aby w cieśni było: jeśliby przestrone, trzeba je też zaprzeć, by się nazad nie cofnęło, bo by przez to skaziło miarę swoję. [...]

Działa zasię małe polne zowiemy Uffnice, Szlęgi, Pułhakownice, te zasię pomagają wiele ku potkaniu z nieprzyjacielem w polu, zwłaszcza gdy je puści z miejsca zatajonego, skąd się nieprzyjaciel nie ostrzeże $[. . .]^{69}$.

Bielski wymienia nie tylko nazwy armat, ich imiona własne, ale i pospolite nazwy, odnoszące się do kalibru dział. Źródła zaświadczają zresztą, że nierzadko przyznawano im nawet imiona dwuczłonowe, $z$ których pierwsze określało właśnie średnicę lufy, drugie zaś było, by tak rzec: tym faktycznym (np. Kartana Smok). Nadanie imienia działu żołnierze zawsze uroczyście celebrowali, to oni zresztą stawali sie „ojcami chrzestnymi” owych machin, z którymi byli bardzo związani emocjonalnie, niecierpliwie oczekiwali na ich pojawienie się w obozie, dbali o nie, traktowali niemal jak towarzyszy broni. Utrata armaty stanowiła największe nieszczęście, jakie mogło się przytrafić na froncie, godziła w honor rycerski (zdarzało się, że żołnierze po odebraniu im armat przez wroga popełniali samobójstwo), zdobycie zaś działa łączyło się $z$ niewyobrażalnym tryumfem ${ }^{70}$.

Najczęstszymi imionami nadawanymi działom były te związane $z$ nazwami gatunkowymi groźnych stworzeń. Szczególnie chętnie więc nazywano armaty Smokami, Wężami, Lwami (te imiona nosiły najcięższe działa, czyli kolubryny), zdarzały się także Wilki, a nawet Koty czy Rysie (dwie ostatnie nazwy były zarezerwowane dla dział ognistych, tj. miotających płonące kule), nie brakowało też ptaków (zwykle drapieżnych), jak Sokół, Sowa, choć w tym gronie znalazła się także Papuga (ptasie imiona dość często nosiły działa lżejsze od kolubryn, typu falkonet - od łacińskiego słowa ,falco", tj. 'sokół'). Imionami zwierząt już nie tak bardzo groźnych, jak choćby Słowik czy Świerszcz, nazywano zaś działka mniejsze, ale dużego kalibru (moździerze). Miało to swoje uzasadnienie, ponieważ egzemplarze tego typu miotały kule, które latały ze straszliwym świstem, przypominającym odgłosy wydawane przez wzmiankowane stworzenia (dźwięk takich dział brzmiał jak śpiew gigantycznego świerszcza czy słowika, stąd też nazwy armat).

Każda armata była więc nie tylko jednookim zwierzęciem noszącym swoje imię, ale - jak zaświadczaja napisy na armatach, które zostaną tu jeszcze omówione istota świadomą swojej mocy i funkcji, jaką stanowiło chronienie swoich, lecz zabijanie wrogów. Co to jednak znaczy, że z działem - rzeczą przecież martwą - wiązała się „świadomość”? Wyjaśnia to Tadeusz Nowak, który wspominając o swoistej „samoświadomości” dział, ma na myśli napisy sformułowane w pierwszej osobie (pojawiają się one nader często!). Dowodzi to, że ich twórcy oraz późniejsi użytkownicy faktycznie traktowali je jak byty ożywione. Widzimy zatem np. miotającego kule Smoka, który tak przedstawia sam siebie: 
Draco sum natus, regibus regnoque poloniae parere, regni fines tueri, hostes murosque hostiles flamma, fulmine ruere [...]. [Urodzony jestem jako Smok, by podlegać królom i królestwu polskiemu, niszczyć wrogów i wrogie mury goracem i piorunem.] [N s. 382] ${ }^{71}$

Smok zatem „mówi” wprost, w pierwszej osobie: „Urodzony jestem jako Smok” (jestem Smok).

Zwierzę o jednym oku w Gadce „zawżdy stoi w kroku” - i rzeczywiście XVI-wieczne armaty, posadowione we wspaniałych łożach, sprawiały wrażenie, jakby ciaggle stały w rozkroku, przyjmując pozycję bojową, pozycję stałej gotowości do ataku. Nawet jeśli odczytać ten fragment w sposób niedokładny (jak czynili to poprzednicy, ograniczający się do definiowania słowa „stać” jako: 'być umiejscowionym, znajdować się w kroku 〈= kroczu〉'), i tak niczego to nie zmieni, i sens wiersza zostanie zachowany, gdyż lufa armaty, posadowiona między kołami łoża, istotnie wygląda tak, jakby była ulokowana w jego „kroczu”. Należy tu jeszcze przypomnieć, iż czasownik „stać” we wzmiankowanym znaczeniu odnosi się do obiektów wystających ponad otaczająca je powierzchnię i zachowujących pozycję pionową: a zatem od razu widać, że proponowana przez Grześkowiaka i Edera picza (a nawet rzyć) stać po prostu nie może (a co najwyżej leżeć, tkwić lub po prostu: być w kroku). Na brak związku owego czasownika z żeńskim organem płciowym wskazują także przywołane przez Grześkowiaka utwory, w których „kiep wła s ny” nigdy nie „s t o i”, ale „s i a d a” (oczywiście - „u dupy”). Czasownik ten różni się od czasownika „stać”, stanowi jego semantyczne przeciwieństwo: antonim, podobnie jak i „leżeć”72. To czasowniki typu „siadać” (albo „siedzieć”) lepiej przedstawiają anatomię „członków tajemnych” niewiasty, użycie owych czasowników w wymienionych tekstach jest zamierzone i jak najbardziej trafne.

\section{„Ślepym bełtem w nie strzelają, A na oko ugadzają"}

Przyjrzyjmy się teraz kolejnym dwóm wersom fraszki i postarajmy się je właściwie odczytać, tego bowiem nie uczynili ani Przyborowski, ani Krzyżanowski, ani Pelc, którzy wprawdzie w jednookim zwierzu dopatrzyli się armaty, ale nie potrafili opisać, co się w wierszu z ową armatą dzieje. Problem ze ślepym bełtem mieli zreszta również badacze współcześni.

Cóż to takiego - ów ślepy bełt, którym jacyś nieokreśleni „oni”, jak trafnie dostrzegła Duska, strzelają do biednego zwierzęcia? Moim zdaniem, nie jest to „okragła kula”, jak chcieli badacze - zwolennicy rozwiązania artyleryjskiego, ani też „pocisk, który nie wybucha, ani nie eksploduje”, ale stempel, służący, z jednej strony, do nabijania armaty, ładowania jej, $z$ drugiej - do przeczyszczania lufy ${ }^{73}$. Był on

Skrótem N odsyłam do: T. M. N o w a k, O „mówiacych działach” artylerii polskiej XVI-XVIII wieku. „Napis” 2006. Wszystkie inskrypcje łacińskie podaję z tej pracy, ale w kilku miejscach przekładam je sama, ponieważ niektóre ich tłumaczenia polskie w tym artykule nie są według mnie zadowalające.

73 D u ska, op. cit., s. 352-353. Trzeba tu nadmienić, że u J. Ko c ha now s ki e go bełt występuje tylko dwa razy: w Gadce i ponownie - we fraszce I 8 Z Anakreonta (KF s. 6-7), zresztą erotyku z elementami batalii. 
stosowany naprzemiennie $\mathrm{z}$ wyciorem lub grajcarem, stanowiącymi właściwe przyrządy do utrzymywania broni w czystości, nierzadko zaś je zastępował. Stempel ma postać długiego kija, przypominającego broń drzewcową, z tępą nasadką na końcu ${ }^{74}$, ułatwiajaccą ubijanie prochu wewnattrz lufy i wpychanie do niej kuli. Stemple epoki Kochanowskiego, podobnie jak bełty, wytwarzano $z$ drewna, $z$ wyglądu przypominały one ślepe bełty. A oto jak skomplikowaną czynnością było nabijanie armaty przy użyciu takiego sprzętu:

To sprawiwszy [tj. ustawiwszy dobrze działo], ma [puszkarz] towarzyszowi swemu kazać przystapić, beczkę albo wór, w którym proch jest, podać, sam zaś szuflę pełną prochu nabrać (jednak nie wierzchowato, dlaczego ma zadni koniec szufle ręką trochę u d e r zy ć, aby co się nazbyt nabrało, odpadło) i w działo wsypać, tak daleko w et kn ą w s zy, aż się o zad działa otrąci, i stamtąd na szuflę na zad na dwa palce pociagnąć, onę wywrócić, proch wysypać i znowu wyciagnaḉ; wyciągając, kiedy już do gęby przychodzi, ma szuflę trochę do góry podnieść, aby prochu, jeżeli się go w rurze rozsypało, nie wyciąną̧ i nie podeptał. Zatym ma stemplem (który tak ma w działo w et $\mathrm{kn}$ ą ć, aby na spodek rury on przyc is k a ł, żeby tak co rozproszono, z sobą zabrać mógł) pomieniony proch nazad do komórki prochowej w garnać i zbić dobrze, co potym obaczy, kiedy zapał pełny będzie, który towarzysz jego ma palcem zatkać, aby się w przyciskaniu nie wysypował. To uczyniwszy, ma drugą szuflę prochu nabrać i także wsypać i z b i ć; potym ma wiązkę ze słomy, z siana, z zgrzebi albo z czego inszego, trochę ciasną (aby się proch rozsypany w rurze zagarnął i zabrał) we t k n ą ć i mocno w b i ć. A jeżeli mu czas dopuszcza, ma rurę jeszcze raz wy chę do ży ć, aby w niej żadnego prochu nie zostało, dla którego by się mógł niebezpieczeństwa obawiać, i ma towarzyszowi swemu rozkazać, aby dobrze kulę otarł, żeby i jedna drobina piasku na niej nie została. Potym ją ma, obwinąwszy w trochę zgrzebi, w działo wolno w s a d zi ć i we p chn ą ć aż do wiązki samej. Gdzie uważać potrzeba, kiedy kulę w py c ha, żeby nie prosto przed działem stał, ale trochę stroną, bo w tych rzeczach bynajmniej nie potrzeba dowierzać. Na koniec ma jeszcze jednę małą wiązkę na kule p obić, co uczyniwszy, będzie działo dobrze nabite ${ }^{75}$.

Oczywiście, od razu trzeba by odpowiedzieć na pytanie, które się nasuwa: jak nabijanie armaty-zwierza powiązać ze strzelaniem? Przecież to są zupełnie inne (zadawałoby się) czynności! Otóż niekoniecznie, o czym zresztą świadczy zacytowany fragment, pokazujący, jak wiele czasowników (podkreśliłam je w tekście) mogło

B. Zd roj e w s k a, Bett. Hasło w: Stownik polszczyzny XVI wieku, t. 2 (Red. S. B ą k [i in.]. Wrocław 1967), s. 43. W słowniku tym, moim zdaniem, nie został odsłonięty właściwy sens fragmentu „Ślepym bełtem strzelać” w odniesieniu do Gadki Kochanowskiego, pojawia się także błędna definicja samego ślepego bełtu (czyli prawdopodobnie: bełtu wystrzelonego bez celowania). W obronie słownika może przemawiać to, że podaje on również, iż jednym z podstawowych znaczeń „bełtu” jest 'pocisk' - a więc jakikolwiek, nie tylko taki, który się wypuszcza za pomocą łuku czy kuszy, czy też innej broni miotającej. W kartotece Elektronicznego słownika polszczyzny XVII-XVIII wieku znajdujemy natomiast następująca definicję „bełtu”: 'strzała do kusz i proc albo krótka włócznia o niewielkim, wąskim grocie, dziryt'. Dziryt to rodzaj broni drzewcowej, odmiana włóczni istniejąca już w epokach prehistorycznych. Dziryt przeznaczony był do miotania lub do walki wręcz, stosowano go także podczas polowań. Co ważne - był znany i popularny również w Polsce. Występuje zresztą więcej odmian broni drzewcowej, przy której użyciu walczono już to rzucając ją, już to korzystając $z$ niej w walce wręcz, zadając pchnięcia. Przykładem może być włócznia, bardzo często mylona z lżejszym od niej oszczepem, zresztą też służącym do zadawania ran za pomoca pchnięć. Opis strzelania bronią drzewcową pojawia się np. w dziele Ł. Górnickiego Rzecz o dobrodziejstwach z Seneki wzięta (Kraków 1593, s. 68). Dawną broń drzewcową prezentuje opracowanie autorstwa J. Kr u c z ka, Arma Ofensiva. Broń ręczna z minionych stuleci (Pszczyna 2014), zawierające ilustracje przedstawiające poszczególne rodzaje takiej broni.

75 D. U fan o, Archelia. W zb.: Polskie wojskowe piśmiennictwo techniczne do roku 1764. Oprac. T. M. N ow a k. Warszawa 1961, s. 101-102. 
służyć opisowi tej czynności. Najpierw należy sobie uświadomić, że ruch towarzyszacy czyszczeniu i nabijaniu takiej broni przypominał ruch, jaki wykonuje się podczas używania (wspomnianej już w związku $z$ budową stempla) broni drzewcowej, np. dzidy, piki, oszczepu, lecz również ślepego bełtu, które nie tylko rzucano, ale też uderzano nimi. Ruch ten także określano mianem „strzelania”, gdyż „strzelać” to (również współcześnie) "uderzać (mocno, z rozmachem)"76. To znaczenie omawianego czasownika odsyła do innego, najbardziej podstawowego, czyli „bić”, który tworzy szereg derywatów, w tym: „nabi(ja)ć” w odniesieniu do broni palnej, samo zresztą słowo „bić” jest używane jako synonim wyrazu „strzelać” (np. 'bić $z$ dział') ${ }^{77}$, można też rozumieć to słowo jako 'atakować, nacierać zbrojnie', 'zabijać', 'polować'78. Jak zaświadcza Krystyna Wilczewska - która przeanalizowała i opisała bardzo dokładnie wszystkie rodzaje tych derywatów dla stanu polszczyzny w XVI wieku, a także ich znaczenia - nabijanie ciężkiej broni jest związane $z$ uderzaniem (co oddaje też czasownik „ubijać”) i łączy się również z pracą, wysiłkiem². Stąd już tylko krok do innego czasownika, także bardzo często używanego w odniesieniu do armaty: „chędożyć” (wraz z derywatami: „wychędożyć”, „wychędożenie”, „przechędożenie”, formą zwrotną „chędożyć się” itd.). Słowo to pierwotnie znaczyło tyle co 'czyścić, sprzątać', ponadto: 'ozdabiać, upiększać', ale jedną z jego podstaw semantycznych jest również 'bić, uderzać' (a nawet: 'trzepać'). Jak stwierdza Beata Raszewska-Żurek, to właśnie znaczenie tego słowa mogło zadecydować o tym, iż zaczęło ono funkcjonować w rozumieniu zgoła odmiennym od prymarnego. Otóż jest rzeczą pewną, że już na początku XVII stulecia czasownik ten był postrzegany jako obscenum, używano go na określenie aktu seksualnego. Pierwszy zapis potwierdzający takie właśnie zastosowanie pochodzi z Liber chamorum Waleriana Nekandy-Trepki, gdzie czasownik ten pojawia się w formie zwrotnej, „chędożyć się” (tu: 'z każdym' - o niewiernej żonie). Możliwe jednak, iż to znaczenie ustabilizowało się już wcześniej w potocznej polszczyźnie i w gwarach ${ }^{80}$.

76 Niejednoznaczność czasownika „strzelać” potwierdzona jest przez materiał z kartoteki SpXVI, gdzie oprócz znaczenia podstawowego ma on też inne, przenośne - m.in. interesujące nas, należące do pola semantycznego czasownika podstawowego „bić” ('uderzyć, trzepnąć). Zob. A n o n i m - Pr o t estant, XVI wieku erotyki, fraszki, obrazki, epigramaty. Z rękopisu wyd. I. C hrzanowski. Kraków 1903, s. 41. Znaczenie to utrwaliło się i występuje w polszczyźnie do teraz, co potwierdzają dzisiejsze słowniki. Zob. Strzelić-strzelać. Hasło w: Uniwersalny słownik języka polskiego. Red. S. D u bis z. Warszawa 2003, s. 1427-1428. Warto dodać, że sytuacja odwrotna (tj. czasownik „bić” jako zamiennik czasownika „strzelać”) częściej występuje w tekstach tworzących korpus SpXVI. Jednym ze znaczeń czasownika „bić” jest 'strzelać, rzucać, miotać', w SpXVI odnotowane w utworach takich jak: M. Bielskiego Sprawa rycerska oraz Kronika wszytkiego świata, J. Mączyńskiego Lexicon, J. Budnego Biblia, M. Stryjkowskiego Przesławnego wjazdu [...]. Widzimy w tej grupie semantycznej wreszcie i teksty J. Kochanowskiego - Monomachię (dwukrotnie pojawia się tam słowo „bić” w znaczeniu 'strzelać’) oraz Szachy, co pozwala stwierdzić, iż poeta zdawał sobie sprawę z tego, że słowo to ma wiele rozmaitych sensów i że wyrazów „strzelać”, „bić” można używać naprzemiennie, grając znaczeniami.

H. Gór s ka, Bić. Hasło w: Stownik polszczyzny XVI wieku, t. 2, s. 110.

79 K. Wil c z e w s k a, Z zagadnień słowotwórstwa i semantyki. Analiza XVI-wiecznej rodziny czasownika „bić”. Wrocław 1977. Uwagi dotyczące derywatów związanych z bronią palną znajdują się na s. 62 .

80 Zob. B. Ras z ew s k a - Żu r ek, O nietypowym rozwoju znaczeniowym w polszczyźnie-czasownik „chędożyć. „Slavica Wratislaviensia” 2014. 
Przedstawiona analiza semantyczna nie tylko pokazuje związek nabijania stemplem ze strzelaniem, ale i wyjaśnia, dlaczego obraz ładowanej tak armaty mógł budzić skojarzenia erotyczne. Posuwiste ruchy stempla w kanale rury przywodziły na myśl jedno, a czynność szła w parze $\mathrm{z}$ określeniem (za pomocą czasowników, które już najprawdopodobniej i w XVI stuleciu odnosiły się do sfery intymnej) ${ }^{81}$. Zarazem wszystkie czasowniki oraz w ogóle słowa związane $\mathrm{z}$ obsługiwaniem armaty: „chędożenie”, „wychędożenie”, „przechędożenie”, „nabijanie”, wreszcie pojawiające się u Kochanowskiego „strzelanie”, mają wspólny rdzeń znaczeniowy, jakim jest czasownik podstawowy „bić” w swoim najbardziej pierwotnym znaczeniu "wykonując szybki ruch doprowadzić do krótkotrwałego, szybkiego zetknięcia czegoś z jakaśs powierzchnią, uderzać'82.

W pracy dotyczącej armat, Ideowa wymowa ozdób armatnich z przełomu XVI i XVII wieku, Karol Łopatecki wspomina o tym, że słownictwo wojskowe mogło kształtować potoczną odmianę polszczyzny. Jednocześnie badacz zaznacza, że dowodów potwierdzających taki wpływ jest mało, gdyż prości żołnierze rzadko prowadzili jakieś zapiski, a jeśli już, to zachowało się tego niewiele. Autor wzmiankowanej pracy podaje np. wejście do języka potocznego typowo żołnierskiego zwrotu: „apostołować ogniście”, czy wyrażenia „ogień apostolski”. Oba frazeologizmy sa związane $z$ najwspanialszymi działami, jakie kiedykolwiek odlano w Polsce (już w XVII wieku). Ponieważ było ich 12 , nazwano je Apostołami: każde z nich nosiło imię jednego z uczniów Chrystusa ${ }^{83}$. Spotykamy zresztą i dziś podobne zwroty, choćby „strzelić kula w płot”, pochodzące wprost z gwary żołnierskiej i oznaczające 'chybić, spudłować, nie trafić'. Niewykluczone, że podobny był los czasownika „chędożyć”: pierwotnie znaczył (po prostu) 'czyścić lufę armaty', a potem nabrał zabarwienia obscenicznego. W kontekście omawianego słowa swoistej pikanterii całej sprawie może dodawać jeszcze ciekawostka, iż armia polska za Zygmunta Augusta (dokładnie wtedy, kiedy tworzył Kochanowski) miała na wyposażeniu potężne działo o nazwie Baba ${ }^{84}$, które żołnierze niewątpliwie chędożyli $\mathrm{z}$ wielką

Jest rzeczą pewną, że czyszczenie i nabijanie broni stemplem kształtowało wyobraźnię erotyczną twórców XVII wieku. Wymownym przykładem może być np. poemacik J. A. M or s zty na o znamiennym tytule Nieobiecany kasek (Białystok 1990, s. 104-105):

\footnotetext{
Podkasałem jej aże pod ramię ciasnoszke

I chcąc się pomścić przeszłych ogniów moich troski,

Wymierzyłem ją na piąź niżej pepka z krzoski.

Jużem stemplem nabijał, a chociaż był gruby,

Zdało się, że dochodził aż do tylnej śruby;

Już jej oczy w słup poszły, już chętnie czekała,

Sprężyna rychło $z$ cynglem wypchnać kulę miała -

A ̇̇ wtem bezecna baba, baba nieszczęśliwa,

Przeklęta, wyszpocona, bezecna, brzydliwa

(Czy-ć ją diabeł obudził?), tak jak była wstała,

Weszła do nas i kiedy najlepiej, przerwała.
}

Na ten utwór zwrócił mi uwagę Radosław G r z e ś k o w i a k, zacytował go w jednym ze skierowanych do mnie listów, które pisaliśmy do siebie i które stanowiły wymianę zdań na temat Gadki. Mój rozmówca uznał wówczas, że nie da się pogodzić czynności strzelania i nabijania stemplem.

Zob. Wilczews ka, op. cit., s. 15.

Zob. Ło patecki, op. cit., s. 252.

Była zatem Baba działem wyjątkowym, gdyż w tym okresie nazwy nie kojarzące się ze zwierzętami stanowiły rzadkość. Armatę ową wymieniono w dokumentach z 1565 roku, a więc bliskich dacie 
ochota... I dobrze, albowiem sroga „niewiasta” miała iście ognisty temperament. Uwidacznia go napis widniejacy na tej armacie: „Z mych piersi buchaja płomienie [...]”, N s. 391), nie pozwalała się zbliżać do siebie byle komu. Jak „sama” poświadcza, bezlitośnie obchodziła się z tymi, którzy się z nią nie liczyli i nie należeli do pocztu jej przyjaciół. W niczym nie przypominała potulnej, wojennej branki, $\mathrm{w}$ starciu $\mathrm{z}$ napastnikiem wylewającej łzy, ale w tych, którzy zbliżali się z niecnymi zamiarami - ciskała pioruny:

Baba vocor bello. Surgunt mihi pectore flammae. Dum speras lachrymas, fulmina mitto. Cave. [Na wojnie wołają na mnie Baba. Z mych piersi buchają płomienie, gdy spodziewasz się łez, ciskam pioruny. Strzeż się.] [N s. 391]

\section{„A na oko ugadzają"}

Wiemy już, że do rozkraczonego zwierzęcia o jednym oku strzelają ślepym bełtem, zobaczmy zatem, jakie są tego skutki...

Tylko co przez to właściwie rozumieć? Czy to, że trafiają (tym ślepym bełtem) w oko zwierza? Czy może to, że trafiaja „na oko”, a więc pewnie, bez wątpienia, nie chybiając celu (jak chciał Pankowski). W odniesieniu do armaty w zasadzie nie wydaje się to tak istotne: sens wiersza będzie bowiem zachowany przy obu sposobach jego odczytania. Trudno rozstrzygnąć, czy właściwa jest pierwsza, czy druga lekcja, ale skłaniam się, by uznać, że to Pankowski miał (w wypadku tego tylko wersu) rację. Ponieważ o wiele bardziej kunsztowna pod względem poetyckim wydaje się zabawa słowem, opalizowanie znaczeń (raz: oko jako narząd wzroku, następnie zaś we frazeologizmie) niż poprzestawanie na jednym znaczeniu wzmiankowanego leksemu. Dodatkowego świadectwa dostarcza materiał z kartoteki SpXVI, gdzie czasowniki „ugadzać” oraz "ugodzić” łączą się w zasadzie tylko z przyimkiem „w”, a nie „na”. Co należy stanowczo podkreślić: łączliwość taka pojawia się także u Kochanowskiego. We wszystkich innych utworach poety (wyjąwszy Gadkę), w których czasowniki te występują, wiążą się jedynie $\mathrm{z}$ „w" wszędzie tam, gdzie rozumiane są jako: 'celując, trafiać w co'. A zatem sugestia Edera, dopatrującego się w „ugadzaniu na oko" obrazu spółkowania, chyba nie da się utrzymać. Celny przykład stanowi wprawdzie cytat $z$ fraszki $O$ flisie (II 86) - rozpłomieniony przez wdzięki gospodyni flisak „w grosz ugodził”, który to zwrot (w sensie podstawowym równoznaczny z innymi - „trafić w sedno”, „w punkt”85) występuje tu w rozumieniu przenośnym: „odbyć stosunek seksualny” (zlekceważywszy zresztą zaporę w posta-

wyprawy radoszkowickiej. Obok Baby posiadał Zygmunt August jeszcze we wzmiankowanym czasie kilka takich dział o nietypowych imionach. Były to: Augustus, Witold, Żebrak (brat-bliźniak Baby). Zob. Strzelba i munitia własnym nakładem JKM sprawiona $w$ Wilnie i na zamki pograniczne rozesłana. Wilno 1565. W: M. Balin ś ki, Historia miasta Wilna z rycinami. T. 2. Wilno 1836, s. 140. - K. Gó r s ki, Historia artyleryi Polskiej. Warszawa 1902, s. 56-57, 344, 383. Wiadomo, że Baba (oraz wymienione wraz z nią działa) istniały jeszcze w 1603 roku.

85 Stownik polszczyzny XVI wieku inaczej wprawdzie definiuje ten zwrot, jak i samo słowo "grosz”, lecz moim zdaniem, nie jest ono tam objaśnione właściwie. „Grosz” to (tak dawniej, jak i współcześnie) drobna moneta o najniższym nominale, w przenośni: 'coś drobnego, małego' ('maleństwo', 'fraszka' 〈Grosz. Hasło w: Stownikjęzyka polskiego [...] do podręcznego użytku. Wypracowany przez A. Zd an owicza [i in.]. Wydany staraniem i kosztem M. Orgelbranda. Cz. 1. Wilno 1861, s. 374)). I to od tego znaczenia według mnie należy wywieść zwrot „w grosz ugodzić”. 
ci mężowskiej ręki) - ale interesujący nas czasownik łączy się z przyimkiem „w”, nie zaś „na”.

A więc czasownik ten może służyć jako podstawa takiego (tj. erotycznego) obrazowania, choć wcale nie musi, lecz jeśli już tak się dzieje, to (jedynie!) wówczas, kiedy łączy się z przyimkiem „w”, co ma - jak pokazałam - znaczenie, gdyż „ugadzać na” w tekstach Kochanowskiego nie musi być wcale równoznaczne $z$ „ugadzać w”. A oto wszystkie przykłady, zawierające połączenie „ugadzać (albo ugodzić) w” (także w sensach przenośnych, dotyczących abstraktów), jakie pojawiają się w dziełach czarnoleskiego poety, stanowiące jednocześnie materiał leksykograficzny SpXVI:

Abyś u swych był wdzięcznym i miłym w pokoju,

A pohańcom zaś srogi i straszliwy w boju.

Tak róść, piękny Michniku, jakobyś pospieszył

Wiekiem, a oczy jeszcze dziadowskie nacieszył,

Siedzac na dzielnym koniu i łukiem władając

Albo kopiją gładką w pierścień ugadzając,

A potym i prędkiego strzelca Tatarzyna,

Co mężnym Radziwiłłom twoim nie nowina. [Małemu wielkiej nadzieje

Radziwiłłowi, KF s. 12]

Ale smutnemu trudno śmiech przychodzi,

Trzeźwy w pijanych sprawy nie ugodzi. [Pieśń VIII, KFr s. 25]

Niech ja też co o tobie powiem, Włodzisławie:

Acz mój dowcip trudno ma w to ugodzić prawie. [Fragment bitwy

Z Amuratem, KFr s. 41]

A kto by chciał rozumem wszystkiego dochodzić

I zginie, a nie będzie umiał w to ugodzić. [Pieśń IX. Księgi pierwsze, KP s. 10]

Ty mię ratuj, a swoją strzała uzłoconą

Ugódź w serce, a okróć myśl nieunoszoną

Zapamiętałej dziewki [...]. [Do miłości, KF s. 96]

wzniówszy gzła, [mąż gospodyni] nakrył dłonią cisa.

Usnął, ściany się wsparłszy: flis ku paniej godzi,

Onej też nie od tego, ręka tylko szkodzi.

„Namniejsza to” (rzecze flis) także miedzy spary,

W grosz ugodził, dobywszy krzoski z szarawary. [O flisie, KF s. 134]

Twe ostre strzały są nieuchronione,

Temi ugodzisz w serca zajątrzone

Swych nieprzyjaciół [...]. [Psalm XLV, KPs s. 67]

Barziejci kędy indziej rzeczy więc zachodzą,

A przedsię mądrzy ludzie łatwie w to ugodza,

Że przywiodą w swą miarę, co się wykroczyło:

Ale trzeba, żeby tam uporu nie było ${ }^{86}$.

Zacytowany materiał pokazuje, że czasownik „ugadzać/ugodzić” w znaczeniu 'celując, trafiać w coś' - wiąże się w tekstach Kochanowskiego z przyimkiem „w” i fakt ten stanowi dla owych tekstów regułę. To pozwala przypuszczać, że połącze- 
nie „ugadzać na co (czyli: oko)” sygnalizuje coś innego niż trafianie w oko oraz że spotykamy się tu raczej z grą słowną: leksem pojawia się raz w znaczeniu podstawowym (oko = "narząd wzroku'), raz zaś we frazeologizmie (połączenie "na oko" = 'pewnie, dokładnie', przy czym wyrażenie to w tekstach XVI-wiecznych zawsze pozostaje w zwiazku z postrzeganiem wizualny m; zatem: owa dokładność, precyzja ma swe źródło w percepcji za pośrednictwem oka, zmysłu wzroku). Oczywiście, ktoś może stwierdzić, że pisarz czarnoleski wybrał taki przyimek celowo. Gdyby bowiem powiedzieć: „A w oko ugadzaja”, to nie zostałby zachowany rytm wiersza. Byłabym skłonna to uznać, ale przecież dla tak wprawnego poety, za jakiego i dziś uchodzi Kochanowski, to nie stanowiłoby problemu, bo łatwo daje się obejść poprzez zastosowanie (choćby) takiej frazy: „A w oko je ugadzaja”, czy też np. „w oko śmiele (albo: silnie, mocno) ugadzaja” (kombinacji jest naprawdę wiele i nie trzeba być poetą tej miary, co Kochanowski, żeby sobie jakąs stworzyć). Autor Gadki wykorzystał więc to połączenie raczej nie dlatego, że nie miał wyboru, ale właśnie dlatego, że chciał powiedzieć co innego, niźli po prostu: „trafiają zwierzę w oko”. Pokazane tu przykłady ilustruja, iż używa on słowa „ugadzać" (vel „ugodzić") w interesującym nas znaczeniu (tj. "celując, trafiać w coś) tylk o (!) z przyimkiem „w”. Jeśli już pojawia się połączenie „ugodzić na”, to w innym sensie. W materiale słownikowym znajdują się zaledwie dwa (wyjąwszy Gadkę) takie użycia. Jedno pochodzi z Psałterza, a zatem z tekstu biblijnego, gdzie pewne połączenia są na swój sposób utarte (tu w znaczeniu - 'trafić, nastąipić):

\author{
Aniołom swoim każe cię pilnować, \\ Gdziekolwiek stapisz, którzy cię piastować \\ Na ręku będą, abyś, idąc drogą, \\ Na ostry krzemień nie ugodził nogą. [Psalm XCI, KPs s. 139] $]^{87}$
}

Kolejne wywodzi się z Fragmentów (i znaczy: 'trafić, natknąć się, spotkać'):

\author{
Niestetyż, by ten najeznik tak młody \\ Nie popadł jakiej znakomitej szkody, \\ Jeśli gdzie na lwa nieborak ugodzi, \\ Który po szyję we krwi ludzkiej brodzi. [Pieśń III, KF s. 17]
}

To pozwala stwierdzić, że w Gadce Kochanowski chciał prawdopodobnie jednak powiedzieć coś zgoła innego niż to, iż zwierze „dostaje” ślepym bełtem w oko, zresztą: po co ktoś miałby próbować strzelić mu w oko, oślepić je? Na dodatek przy użyciu dość zawodnego narzędzia, jakie stanowi ślepy bełt? Tego rodzaju działanie przeczy zasadom polowania, podczas którego strzela się do celu, zatem tak, żeby trafić i zabić, a nie by pozbawić wzroku.

Sądzę, że nie jest to jedyna w Gadce gra słowna, ale że i omówiony tu właśnie fragment, gdzie opisane zostało strzelanie do jednookiego zwierza, stanowi również wyrafinowany zabieg poetycki, służący wprowadzeniu czytelnika w błąd i mający za zadanie odciagnąc jego uwagę od przedmiotu właściwego (armaty, z której, a nie: do któ rej się strzela) i skierować ją w inną stronę. Jeśli jest to słuszna intuicja, to zachodziłoby w Gadce swego rodzaju odwrócenie porządku: to, co

87 W Nowym Testamencie (Kraków 1593) w przekładzie J. W uj k a ten sam fragment jest oddany jako „i będą cię na ręku nosić, abyś snadź nie obraził o kamień nogi twojej” (Mt 4,6). 
zwykle strzela i zabija, tu staje się ofiarą. Trzeba przyznać, że ma to sens w świetle definicji zagadki jako takiej, która pewne przymioty opisywanej rzeczy zakrywa albo zgoła ukazuje je w sposób przeciwstawny, aby zgadujący dokonał wysiłku; ale też zawiera elementy odkrywające i naprowadzające, żeby jednak w finale rozwiązanie jej było możliwe. W tym wypadku słowo „strzelać”, które stanowi przecież o istocie armaty, po pierwsze nakierowuje na właściwy przedmiot zagadki (czytelnik dostaje sygnał, że chodzi o strzelanie), po drugie - kamufluje wszystko, bo to armata strzela, a nie odwrotnie ${ }^{88}$.

„Głos jego, by piorunowy,

A zalot nieprawie zdrowy"

Gadka dostarcza nam jeszcze dwóch informacji na temat opisywanego monstrum. Zatrzymajmy się na pierwszym z przymiotów, jakim jest „głos piorunowy”. Otóż wszystko wskazuje na to, że taki właśnie głos należeć może do zwierzęcia-armaty. Istnieje wiele przesłanek zarówno w XVI-wiecznym piśmiennictwie, jak i w ikonografii (konkretnie mam tu na myśli wizerunki widniejące na broni palnej pochodzącej z czasów Kochanowskiego), które to potwierdzają. Świadczą o tym także napisy na działach. Bardzo często eksponowano ich związek z piorunami, gromem, a więc armaty bywały zdobione nierzadko wyobrażeniami piorunów, odlewano na nich również postacie trzymające błyskawice w dłoni i ciskające nimi (w domyśle: we wrogów) ${ }^{89}$. O swoich zwiazkach $z$ gromem „mówią” też same armaty. Taki np. Wielki Wąż straszy adwersarzy piorunem. I to nie byle jakim, ale zawierającym jad siarczany:

Magnus ego Serpens. Sum magnus et hostibus hostis. Fauces sulfureum fulmina habent. [Jam Wielki Wąż. Jestem wielkim nieprzyjacielem wrogom. Pioruny z mej gardzieli zawierają siarczaną truciznę.] [N s. 388]

\section{Także Sokół ostrzega:}

Falco vocor rostro defalco cum tare curvo. Terrificum gero fulmen in ore. Cave. [Nazywam się Sokół, zakrzywionym dziobem koszę. Straszliwy piorun noszę w paszczy. Uważaj.] [N s. 388]

Natomiast Filomea (tj. Słowik), choć w mitologii była bezbronną dziewczyną, to przemieniona w armatę, staje się mścicielką swych krzywd, miotającą pioruny na wrogów (którym jawi się raczej jako złowieszczy Puchacz - Bubo), ale tym, których

Tak istotę zagadki wyłożyła T. M i c h ał ow s k a (Staropolska teoria genologiczna. Wrocław 1974, s. 158): „Niektóre definicje głosza, iż jest to utwór opisujący jakaśs ukrytą rzecz poprzez ewokowanie jej cech albo porównywanie $z$ innymi rzeczami, czy też wskazywanie rzeczy opozycyjnej względem niej”. Potwierdzają to wspomniane już prace Kasja na (Polska zagadka ludowa, s. 8): „Zagadka jest, mówiąc najogólniej, rodzajem zadania umysłowego, które polega na tym, by zidentyfikować jakiś przedmiot na podstawie jego charakterystyki słownej. Charakterystyka ta, co jest bardzo ważne, składa się z określeń konkretnych, obrazowych. Musi być pomyślana oczywiście w taki sposób, by umożliwiała identyfikację, nie czyniąc jej jednak zbyt łatwą; musi więc jednocześnie odsłaniać i ukrywać".

89 Zob. T. N ow a k, Rysunki dział zdobytych przez Szwedów $w$ Polsce $w$ XVII i na poczatku XVIII $w$. „Studia i Materiały do Historii Wojskowości” 1976, s. 308, 320. - Ło p a te c ki, op. cit., s. 250. 
broni - śpiewa piosnkę. Ten zgrabny napis łączy więc wzrokowo-akustyczny efekt błyskającego i grzmiącego pioruna $z$ dźwiękiem świstających kul:

Sum Filomena tibi, sed dirus ad omnia Bubo. Hospitu cantus, fulmen at hostis habet. [Dla ciebie jestem Filomena, ale dla wszystkich innych złowieszczym Puchaczem. Dla przyjaciół mam śpiew, ale wróg otrzymuje piorun.] [N s. 389]

Dodatkową przesłanką może być jeszcze to, że kiedy Kochanowski używa przymiotnika „piorunowy”, to pojawia się on w wyrażeniu „strzelba piorunowa” w Pieśni świętojańskiej o Sobótce:

Bodaj wszytkich mąk skosztował,

Kto naprzód wojsko szykował

I wynalazł swoja głowa

Strzelbę sroga piorunowa. [Panna X, KP s. 67]

Zresztą nie tylko Kochanowski miał takie właśnie wyobrażenie o broni palnej, ale ów obraz (a raczej powiązanie dźwięku z obrazem) utrwalił się w literaturze i piśmiennictwie do tego stopnia, że jeszcze i u Adama Mickiewicza znajdujemy piorun w zestawieniu z bronią palną. Przykładu dostarczyć może choćby epos Pan Tadeusz (gdzie w scenie polowania, przedstawianej przez Wojskiego, pojawia się „ton twardszy jak grzmot: to strzelanie"90) czy Konrad Wallenrod (i opowieść o chłopcu, który „Broń piorunową urządza [...]”91) oraz oczywiście Reduta Ordona (w której: „dwieście armat grzmiało [...]"92). Ten typ obrazowania był popularny również i w epoce Jana z Czarnolasu. Co warto podkreślić, w utworach z XVI stulecia tak właśnie ukazywano i ciężką, i ręczną broń palną. Kojarzono ją z gromem, a czasem nawet „piorun” wynaleziony przez człowieka przewyższał ten, który - wedle mitologii - dzierżył Jowisz:

Festus, Trzaskanie a puszczanie z dział, podobnie jakoby grzmiało. [M k. 56b]

Dwa słupy przyprawione $z$ prochy zapalono.

$Z$ dział też w dwa rzędy w rynku bito na przemiany,

Ognie świecąc gorzały $z$ wieże zawieszony.

W zamku grom z dział, z hakownic jeszcze więcej srogi,

Tam k bitwie w bębny biją, tam trąbią na trwogi. [S k. C3v]

Gromy, aże ziemia drży, s rogo powtarzali,

$\mathrm{Z}$ prochow dym, płomień straszny [...]. [S k. B4v]

A gdy w Rynek wjechali [goście] i słuch zagłuszyły

Trąby, bębny, i działa zewsząd grom puściły. [S k. C]

$Z$ hakownic też ogromność, aże Wawel drżała,

Ta strzelba pięc godzin w noc prawie straszna trwała.

Iż choćby Jowisz z nieba gromy rozgniewany,

Wszytki zaraz wypuścił, nie byłby zrównany. [Sk. C]

był krzyk wielki i grzmot, tak ludzi, jako koni i strzelby ${ }^{93}$.

A. Mickiew ic z, Pan Tadeusz, czyli Ostatni zajazd na Litwie. W: Dzieła. Wyd. Narodowe. T. 4. Objaśn. J. Krzyża n ow s ki. Kraków 1949, s. 122.

A. Mi cki ew i c z, Konrad Wallenrod. W: jw., t. 2: Powieści poetyckie (Objaśn. K. Gó r s k i), s. 108.

A. Micki ew ic z, Reduta Ordona. W: Poezje [...]. Oprac. J. C z e c h ow i c z. Warszawa 1939, s. 5.

M. Bi els ki, Kronika, to jest Historyja świata [...]. Kraków 1564, k. 411v. 
Konie rżą, grzmot, gdy zbroje o zbroje chrzęściały,

$Z$ ruśnic trzask, dym, a strzały pierzyste świszczały [... $]^{94}$.

Wydaje się, że już te tylko wybrane przykłady dostatecznie dowodza, iż przymiotnik "piorunowy” oraz leksyka związana z burza, hukiem, piorunami były w czasach, kiedy powstawała Gadka, nieodłącznym elementem obrazowania scen bitewnych, w których broń palna stanowiła najstraszliwsza ze wszystkich możliwych broni. Co więcej, zdarzaja się w literaturze tego okresu i odwrotne obrazy, tzn. pioruny z nieba ukazuje się jako strzelbę, broń palną:

\author{
Kościoły, wieże dziwne, kształty rozmaite \\ A dziwnym kosztem wszędy przyprawy obfite. \\ Porządki w nich i sprawy jako wystawione, \\ A czasem i nad rozum dziwnie wystrojone. \\ Nuż ony srogie strzelby z nieba trzaskające, \\ Tęcze, burze i ognie groźno błyskające. [RW k. 10v] \\ Patrzaj, jaki to Bóg jest, Pan wszytkiego świata, \\ Jaka jest jego dziwna srogość i zapłata. \\ [. . . . . . . . . . . ] \\ Patrz, jako srogie działa od niego trzaskaja \\ A jako straszne ognie po światu latają. \\ A wszytek świat, gdyby chciał, zniszczyłby w godzinie, \\ Tak jego dziwna możność na wszem dziwnie słynie. [RW k. 49v]
}

Rej w Wizerunku przedstawia również genezę niebieskiego ognia, a zatem próbuje objaśnić, skąd pochodzi piorun. Należy zwrócić baczną uwagę na to, że podstawowym składnikiem pioruna jest proch, który wiatry unoszą w niebo, gdzie dochodzą kolejne ingrediencje, takie jak siarka, stanowiąca przecież najistotniejszy komponenet prochu strzelniczego. Powinowactwo gromu i broni palnej jest więc naprawdę ścisłe, proch wytworzony przez człowieka można uznać za rzeczywisty ekwiwalent ognia $z$ niebios ${ }^{95}$ :

\footnotetext{
Patrzże, gdy mocne wiatry prochy wzgorę wznoszą,

A iż je tam pod niebo wysoko wyniosa,

Gdy przyjdą w ty mokrości, wnet się w kupę zlepią,

A wiatry jako młotem tak to mocno sklepia.

Gdy je zasię do sfery ognistej wyniosa,

Wnet ono prędko wyschnie, co zmoknęło rosa.

Rozpaliwszy się potym, do wody upadnie,

To potym wre a huczy, jako w kotle na dnie.

A kiedy się siarkowe prochy w to wmieszają,

To już oczyma widzisz, iż się zapalają,

A gdy lecą do wody, tedy się błyskaja,
}

M. St ryj k o w s k i, Która przedtym nigdy świata nie widziała Kronika [...]. Królewiec 1582, s. 622. Wpisuje się to w renesansową koncepcję człowieka (rozumianego jako obraz i podobieństwo Boga). Podobnie jak Bóg, jednostka ludzka jest obdarzona zdolnością tworzenia, a tym samym - naśladowania swego Stwórcy. Koncepcja taka pojawiła się już w późnym średniowieczu (Mikołaj z Kuzy), potem zaś była rozwijana przez humanistów, osiągając renesansową pełnię w poglądach G. P. della Mirandoli. Zob. E. C y b u l s k a - B o h u s z e w i c z, „On utwierdzit na wieki niebo niestanowne”. Chrześcijańska wizja kosmosu $w$ poezji polskiej (od połowy XVI do połowy XVIII w.). Warszawa 2010, s. 132-133. 
A upadszy, grzmią, huczą, a czasem trzaskają.

Acz toż czasem ty gromy i wiatry działaja,

Gdy się mocno mieszając o się uderzają. [RW k. 151-151v]

Piorun budzi przerażenie, gdyż jego działanie niszczycielskie jest wszechogarniające:

Trzasnął piorun okrutnie, a gałąź surową

Uciął przy samym drzewie, prawie mi nad głową. [RW k. 110]

Co opisuje zresztą nie tylko Rej, ale i Kochanowski. W Psałterzu kreśli on wizję gromu, który przeraża „wszytki ziemskie granice”:

Chmury z hukiem linęły deszcz niesłychany,

Linęły grad gwałtowny $z$ wichrem zmieszany.

Twoje ogniste strzały, twe straszne gromy

Latały a niebieskie trzaskały domy.

Roiły się po niebie w krag łyskawice,

A strach zdejmował wszytki ziemskie granice. [Psalm LXXVII, KPs s. 114]

Podobny charakter ma wojna, w której to „pioruny” wynalezione przez człowieka zastępują niszcząca potęgę gromów niebieskich. Identyczne są zatem środki leksykalne (zwłaszcza czasowniki: „trzaskać”, „bić” etc.), służące do przedstawiania obu tych zjawisk:

A co zasię z nieszczęścia przypadłej przygody

Przychodzi z każdej strony na ludzkie narody:

Walki, burdy, rozterki, że się hufy walą,

Działa straszno trzaskają, a domy się palą. [RW k. 93v]

\section{„A zalot nieprawie zdrowy”}

I wreszcie wers ostatni czarnoleskiej zagadki. Również pasuje on do wizerunku armaty. Nikt bowiem chyba nie wątpi w to, iż zapach - jaki wydobywa się z lufy piorunowego działa, a będący efektem spalania czarnego prochu, którego główne składniki stanowią: siarka, węgiel i saletra - jest nieprzyjemny, towarzyszacy mu zaś dym nie tylko „niezdrowy”, ale i gryzący, duszący.

Wyjaśnijmy dokładnie, co znajdujemy u Kochanowskiego w omawianym fragmencie. Otóż wyraz „nieprawie” w leksyce XVI-wiecznej miał ustabilizowane znaczenia $^{96}$. Jednakże w pewnych kombinacjach mógł być rozumiany zupełnie przeciwnie, w zależności od tego, co następowało po owym leksemie. Pojawić się mógł zatem w znaczeniu podstawowym, w funkcji zaprzeczenia względem towarzyszacego mu przymiotnika, ergo: 'nieprawie zdrowy' (= 'wcale niezdrowy, nie naprawdę zdrowy'). Taki sposób użycia tego słowa jest charakterystyczny dla poezji Kochanowskiego i pojawia się dość często w różnych jego utworach ${ }^{97}$. Zupełnie jednak inaczej leksem należy odczytywać, kiedy łączy się on z określeniem pejoratywnym. Wtedy tworzy podwójną negację i tym samym - akcentuje znaczenie dodatnie na- 
stępujących po nim przymiotnika, rzeczownika czy przysłówka. Taką konstrukcję spotkać można często zwłaszcza w utworach Reja ${ }^{98}$. U Kochanowskiego natomiast pojawia się ona tylko raz i to nie we Fraszkach, lecz jedynie w Pieśniach (KP 14). To pozwala stwierdzić, że wers Gadki należy odczytywać po prostu jako: 'zapach wcale nie zdrowy (tj. nie będacy ani trochę zdrowy)', etc. Ów „niezdrowy” zapach nie tylko przywodzi na myśl jakiś nieokreślony rodzaj broni prochowej, ale być może dotyczy działka na dwóch kołach, zwanego kozą. Była to armata starego typu, jej użycie zaświadczaja źródła polskie i czeskie już na przełomie XIV i XV wieku (korzystał z nich Jan Olbracht na wyprawie wołoskiej w 1497 roku, dysponował 100 takimi działkami) $^{99}$. Armata-koza dlatego wydaje się dobrym kandydatem na rozwiązanie zagadki, gdyż zwierzę, od którego nazwano ten rodzaj działa, jest w szczególny sposób kojarzone $z$ charakterystycznym, intensywnym, a ponadto niemiłym zapachem ${ }^{100}$.

Przyjrzyjmy się jeszcze niektórym napisom na armatach, konkretnie zaś temu, jak została w nich przekazana informacja o prezentowanym dziale. Czy nie przypominają one omawianej Gadki? Przecież w oderwaniu od opisywanego przedmiotu można bardzo łatwo owe wersy odczytywać jako zagadkę właśnie. Struktura armatnich inskrypcji w jakimś sensie przypomina utwór Kochanowskiego. Wyobraźmy sobie, że ktoś podaje nam takie oto słowa, a my nie wiemy, z jakiego źródła one pochodzą:

Anguis ego, pomum mortemque in gutture porto, pomo captus Adam poma cavete mea. [Jestem Wężem, śmierć i jabłko noszę w gardzieli, Adam zwiedziony jabłkiem: strzeżcie się moich jabłek.] [N s. 388]

Na pytanie: czymże jest ów Wąż miotający śmiercionośne jabłka? nasuwa się odpowiedź tylko jedna - to broń, armata wyrzucająca $z$ siebie zabójcze kule. Za pomocą równie enigmatycznej, a przy tym wyrafinowanej, bo zwięzłej przecie formuły, „przedstawiają się” także dwie kolubryny zwane Syrenami:

Syren ego. Ne tu tenearis carmine nostro. Cantus sunt nostri, funera certa tua - „Syrena jestem, nie żeby zatrzymać ciebie pieśnią. Śpiewy są nasze, a pewny pogrzeb twój”.

Syrena ocoeano quam astu contempsit Ulysses. Terris contra astum fulmina porto modo. [Jestem Syreną na oceanie, podstępem pokonana przez Ulissesa. Na lądzie przeciw podstępowi stosuję teraz pioruny.] [N s. 391]

Zauważmy, że żadna $\mathrm{z}$ wymienionych armat nie wyjawia, czym jest. Nie mówi więc: ,jestem działem/armata/kolubryną" ${ }^{101}$. Zawsze podaje jedynie własne imię i krótką informację o swym „charakterze”. Czyż jeśli oderwiemy owe inskrypcje od

M. Rej: Zwierzyniec [...]. Kraków 1562, k. 85, 86, 86v, 72; Zwierciadło [...]. Kraków 1568, s. 26.

Zob. J. S zy m c za k, Poczatki broni palnej w Polsce (1383-1533). Łódź 2004, s. 58-59.

Stąd np. w języku potocznym czasownik „capić”, tj. 'śmierdzieć', wywodzący się od wyrazu „cap”.

To się zdarzało, ale rzadko (przynajmniej za czasów panowania Zygmunta Augusta). Zob. np. taką „wypowiedź” falkonetu: „sum falconetes, hostis castrisque virisque [...]. Sigismundus Augustus rex Poloniae magnus dux Lithuaniae me fecit anno MDXLIV [...]" [Jestem Falkonet, wróg zamków i wojsk, Zygmunt August, król Polski, książę Litwy mnie uczynił w roku 1544] (N s. 389). Zdecydowana większość armat epoki Zygmuntów nosiła jednak napisy i ozdoby odsyłające do „zwierzęcej” i „piorunowej" natury tej broni. W późniejszych czasach hasła na armatach, jak i ozdoby na nich, stawały się coraz bardziej oszczędne. 
ich desygnatów i odczytamy je komuś nieświadomemu tego, że chodzi o armatę, napis nie brzmi tajemniczo? Któż wie? Może omawiana fraszka była zatem (także formalnie) inspirowana armatnimi napisami, $z$ taką różnica, iż Kochanowski napisy te podał w formie poetyckiej zagadki? Nie wydaje się to wykluczone, zwłaszcza że inskrypcje na armatach często były albo łacińskie, albo niemieckie, co już stwarzało wokół nich aurę tajemnicy, zagadkowości. I choć łacina była w XVI wieku językiem powszechnym, to nie każdy żołnierz ją znał. Żołnierze w ówczesnym wojsku polskim nie tylko pochodzili z różnych miejsc w kraju, ale znajdowało się wśród nich przecież niemało cudzoziemców (np. Litwinów, Niemców, Tatarów, Serbów, Węgrów itd.) ${ }^{102}$. Niewielu zatem potrafiło takie napisy odczytywać. Niewatpliwie mógł to jednak uczynić biegły w łacinie poeta praeclarus.

Kolejna poszlakę, która łączy Gadkę ze wzmiankowanymi napisami na armatach, stanowi to, że w obu wypadkach mamy do czynienia z grami słownymi. Przykładem takiej gry może być choćby cytowana tu inskrypcja na armacie typu falkonet, gdzie wyraz ,falco" ('sokól') wiąże się ze słowem ,falx, -cis" ('kosa'). Straszliwy Sokół grozi, iż skosi wrogów zakrzywionym dziobem. U Kochanowskiego pojawia się natomiast gra znaczeniami (co tu już opisałam). Jeszcze jedna przesłanka zdaje się przemawiać za tym, że geneza Gadki może mieć związek z inskrypcjami armatnimi. Otóż: układali je poeci skupieni wokół dworu Zygmunta Augusta, wiadomo, iż tworzył je Piotr Roizjusz, przedstawiony przez Kochanowskiego we fraszce $O$ doktorze Hiszpanie. $Z$ cała pewnościa jest on autorem napisów na armacie-Sokole, Babie, Wężu ze śmiercionośnym jabłkiem, Słowiku-Filomei, Wielkim Wężu, który zatruwa jadem siarczanym, na obu Syrenach, Zygmuncie, Auguście, a także na kilku innych, tu nie wymienionych ${ }^{103}$.

Jak podaje Maurycy Petzewitz w Historii i opisie polskiego oblężenia, bojowe hasła na armatach ułożone były w heksametrach, przez rymopisów znajdujących się na dworze Zygmunta Augusta. Z późniejszego okresu nie posiadamy wiadomości o twórcach tych paremii ${ }^{104}$.

Wszystkie cytowane tutaj inskrypcje, związane $z$ armatami epoki Zygmunta Augusta, spisane zostały dystychem elegijnym (zwanym też „kulawym heksametrem”), zatem bez wątpienia ułożył je ktoś biegły w sztuce poetyckiej. Kto wie, być może jednym ze wspomnianych królewskich „rymopisów” był nie tylko Hiszpan, ale i jego przyjaciel, Jan Kochanowski? Wszak jego Elegie, Foricoenia i Lyrica operują rozmaitymi formami metrum, $\mathrm{z}$ których każde pojawia się w liryce rzymskiej. Kochanowski zapożyczył je i z dużą kulturą naśladował. Stosunkowo największe

Szczegółowo o składzie wojska, jego oddziałach, zob. Zarys dziejów wojskowości polskiej do roku 1864, s. 296-345.

Na związek Hiszpana z napisami armatnimi trafiłyśmy wraz z koleżanką z pracowni, łacinniczką Anną Nath-Dokurno, która pomagała mi ustalić poprawna wersję inskrypcji na działach (w artykule N ow a k a $O$ „mówiacych działach” artylerii polskiej XVI-XVIII wieku, jak już wspominałam, część $z$ cytowanych napisów zawiera błędy), jak również sprawdzała poprawność moich tłumaczeń. Napisy armatnie (Epigrammata tormentorum) autorstwa P. Ro izj u s za znajdują się w Corpus antiquissimorum poetarum Poloniae Latinorum usque ad Ioannem Cochanovium (t. 5: P. Royzi Maurei Alcagnicensis Carmina. Cz. 2: Carmina minora continens [...]. Oprac. B. Kruczki ewicz. Cracoviae 1900. Także i w tym wydaniu znajdują się błędy).

Ło p a te c ki, op. cit., s. 259. Zob. też J. N ow a k-Dł u ż ew s ki, Okolicznościowa poezja polityczna $w$ Polsce. Pierwsi królowie elekcyjni. Warszawa 1969, s. 105-106. 
urozmaicenie miar znajdujemy w Foricoeniach, w elegiach, zgodnie z tradycją, występuje dystych elegijny składający się z heksametru i pentametru. Ale nie tylko miary wierszowe przeją poeta od poprzedników: można by ułożyć rejestr motywów i wyrażeń zapożyczonych od Katullusa, Tibullusa i Propercjusza. I choć nie jesteśmy w stanie jednoznacznie stwierdzić, że Kochanowski podobne inskrypcje armatnie tworzył, to nie możemy tego wykluczyć, bo ich autorzy nie zostawiali przecież na armatach swych sygnatur:

Nie wiadomo, kto układał teksty napisów odlanych na spiżowych lufach dział. Można przypuszczać, że autorami tekstów zredagowanych w języku niemieckim mogli być ludwisarze, napisy łacińskie układali zapewne zamawiający odlew przedstawiciele fundatorów. Ktokolwiek jednak był autorem napisu, to zawsze starał się nie tylko nadać działu imię, ale także je umotywować i związać z zadaniami, jakie tę broń czekają ${ }^{105}$.

Czy więc autorem któregoś z napisów na licznych działach Zygmunta Augusta albo nawet Stefana Batorego był Jan z Czarnolasu? Nie jesteśmy w stanie tego potwierdzić. Ale też nie możemy temu zaprzeczyć. Niewiele $z$ owych dział przetrwało: część została przetopiona przez kolejnych królów na nowe armaty. Nie ocalały zatem wszystkie inskrypcje, dysponujemy tylko małym wycinkiem twórczości królewskich rymopisów. Odczytanie militarne Gadki wskazywałoby jednak, że Kochanowski mógł być autorem podobnych tekstów i że upamiętnił ten epizod swej biografii właśnie w owej fraszce.

Krzyżanowski, a za nim Pelc, przyjęli jeszcze, iż także muszkiet może stanowić rozwiązanie zagadki. Na początek jednak należy doprecyzować, o jaki muszkiet w istocie chodzi. Otóż źródła wskazują raczej na rusznicę lontową, tzw. lancknechtowską (maksymiliańska), niż na muszkiet właściwy, gdyż ten pojawia się w wojsku polskim później. Opisywana rusznica lontowa funkcjonowała jednak też pod nazwą muszkietu ${ }^{106}$. Jest on wprawdzie mniejszy od armaty, ale potrafi być równie hałaśliwy jak piorun. Działa na proch, a więc i zapach po wystrzale $z$ muszkietu $z$ cała pewnością nie należy do najpiękniejszych. Czyści się go (czy chędoży) stemplem ślepym bełtem. Badaczom przysparzało nieco kłopotu dopasowanie tego rodzaju broni do wersu drugiego Gadki: „zawżdy stoi w kroku”. Forkiet, na którym opierano muszkiet, miał przecież jedną nogę. Wydaje się wszakże, iż jednonożność forkietu nie stanowi problemu, jeśli przyjmie się, iż „krokiem” jest rozgałęzienie wideł u jego szczytu, a zatem właściwe miejsce, gdzie osadza się muszkiet. Gdyby i to nie przekonywało, warto nadmienić, że w XVI wieku istniały podpórki na broń, które miały postać trójnogu (takie są zresztą stosowane i dziś). Broń kładło się na podporze o trzech, niewątpliwie rozkraczonych, nóżkach. Opis sprzętu tego rodzaju znajdujemy u Bielskiego, który w następujący sposób go prezentuje: „Strzelba była żelazna, na nogach by kozy [...]"107. Mamy więc związek muszkietu ze zwierzęciem. Zaiste, źródła potwierdzają, że właśnie podpórkę tego typu określano pierwotnie w Polsce „kozą” (statywy-trójnogi pod broń funkcjonują pod tą nazwą również dziś),

105 Nowa k, O „mówiacych działach” działach artylerii polskiej XVI-XVIII wieku, s. 381.

106 Z. Żygulski Jun., Broń w dawnej Polsce. Na tle uzbrojenia Europy i Bliskiego Wschodu. Warszawa 1975, s. 184.

107 M. Biels ki, Satyry. Kraków 1567, k. D3v. 
„kozią nogą” lub „soszką” ${ }^{08}$. Określenia owe odnoszono potem też do forkietu, zwanego (bardziej swojsko) także „widłami” albo „widelcem”. Co warto od razu zaznaczyć, „kozą” bądź „kozłem” nazywano również trójnóg służący do podnoszenia lufy armaty w trakcie celowania ${ }^{109}$.

No i wreszcie ,jedno oko". Tutaj istnieje kilka możliwości, bo w czasach Kochanowskiego muszkiety były różne i rozmaicie się z nich strzelało. Otóż: z niektórych celowało się „po lufie”, wtedy za oko muszkietu należy uznać jego otwór wylotowy, choć już w połowie XV wieku tego typu karabiny były wyposażone w celowniki (staropolska nazwa to „celik”) o prostej konstrukcji, składające się ze szczerbinki (zwanej też „blizną”) i muszki (tzn. celu), występowały również celowniki rurkowe. W opisywanym przeze mnie przedziale czasowym (a zatem połowa XV wieku) celowniki stanowiły integralną część broni, choć korzystano także z ruchomych nakładek, które dawało się przesuwać po lufie, w zależności od jej długości. Podobnych nadstawek używano również niekiedy przy celowaniu $\mathrm{z}$ armaty, choć w tym wypadku najczęściej chodziło o to, żeby ustawić ją pod właściwym kątem ${ }^{110}$. Być może więc to „oko”-celownik miał na myśli Kochanowski? A może raczej po prostu to, że aby dobrze wycelować ze wszelkiego typu broni ręcznej, strzelec musiał zamknąć jedno oko, drugim zaś mierzyć? Jednooczność była w wojsku walorem, a nie wadą i w żaden sposób nie przeszkadzała strzelcowi w wypełnianiu wojskowego rzemiosła:

Czemu jednoocy dobrzy strzelcy bywają albo czemu strzelający pospolicie jedno oko zamrużają? Odpo. Bowiem wszelka moc gdy pospołu będzie, silniejsza jest niźli rozdzielona. Jako gdy wiele świec społem będą, więtsze światło podawają niż gdy stoją jedna tam druga sam. Tak też moc wzroku, gdy się z obu oczu do jednego zbierze, pewniej rozeznawa i lepiej obacza niźli obiema ${ }^{111}$.

A więc oko „Źwierza” byłoby okiem w pewnym sensie metaforycznym, niejako „pożyczonym” od tego, kto strzela? Może obraz w Gadce dotyczy strzelca, który poniekąd zlewa się, tworzy na polu walki wraz ze swą bronia jakby jedno ciało? To też miałoby jakiś sens, bo muszkieterów nazywano także dragonami i wiązano etymologię tej nazwy ze smokiem. Jest wszakże raczej mało prawdopodobne, że tekst dotyczyłby takiego żołnierza i jego broni, ponieważ dragoni pojawili się w wojsku polskim później, na początku XVII wieku'112.

Jak widać - czarnoleskie równanie rozrasta się i trudno znaleźć jedyną słuszną odpowiedź... Skłaniam się ku temu, by przyjąć, że gdy Kochanowski mówi o oku, ma na myśli po prostu okragły wylot lufy każdej z opisanych broni - czy to armaty, czy to muszkietu - ale nie chcę wykluczać i takiego scenariusza, jak wymienione tu możliwości. Jeśli poeta stacjonował w wojskowym obozie, to patrzył na wszel-

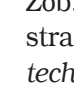
tad stawkach artyleryjskich).

111 Ary s t o tel e s, O widzeniu. W: Problemata. Gadkiz pisma wielkiego filozofa [...]. Przeł. A. G la b e r. Kraków 1535, k. B5v.

112 Zob. Żyguls ki, op. cit., s. 213-214, 216. - R. Matu szew ski, Muszkiety, arkebuzy, karabiny... Warszawa 2000, s. 23-25, 59. 
kiego rodzaju broń $\mathrm{z}$ bliska, chyba nawet sam próbował z niej strzelać, więc i niewykluczone, że mógł dostrzec najdrobniejsze detale. Lecz skoro tak było, to muszę przyznać, iż jednooczność muszkietu dotyczy raczej tego, że strzelec używa jednego oka podczas korzystania $z$ niego. Celownik wydaje się lepszym rozwiązaniem, ale prawdopodobieństwo, iż poeta oglądał broń w niego wyposażoną, jest mniejsze. Rusznice-muszkiety wojskowe czasów Kochanowskiego zwykle były pozbawione przyrządów celowniczych. Zaopatrzona w nie była raczej broń służąca do polowania oraz modele sportowe, przeznaczone do ćwiczeń w strzelaniu do tarczy. W wojsku doby renesansu ręcznej broni palnej nie ceniono ze względu na jej celność: większą wagę przywiązywano do szybkostrzelności i utrzymania ciagłego ognia dłużej ${ }^{113}$. Jednak kto wie, może autor Gadki widział różnego rodzaju bronie, a więc te przeznaczone do działania na froncie, jak i te - lepiej wyposażone - służące do ćwiczeń w strzelaniu do celu? Żywa była przecież jeszcze w epoce Kochanowskiego tradycja rycerska strzelania do kurka, która popisywali się żołnierze ${ }^{114}$. Poświadczaja to teksty twórców takich, jak Rej, Orzechowski, Klonowic czy wreszcie - Bielski ${ }^{115}$.

Pozostaje teraz rozstrzygnąć, czy filologiczna zagadka jest niczym proste równanie liniowe, ma jedno rozwiązanie, czy też stanowi raczej skomplikowany układ takich równań, z przynajmniej dwoma rozwiąaniami? Moja praca to próba odwołania się do ustaleń uczonych takich, jak Julian Krzyżanowski i Janusz Pelc, rozwinięcia ich spostrzeżeń dotyczących Gadki, gdyż ufam, iż intuicje ich były słuszne. Dlatego skłaniam się ku temu, że chociaż utwór Kochanowskiego jest dwuznaczny, a zatem: tak rzyć, jak i broń palna wydają si ę równorzędnymi rozwiązaniami omawianej fraszki, to prawidłowa odpowiedź na zadana przez poete zagadke jest tylko jedna. Nie może być zresztą inaczej, gdyż przeczyłoby to definicji omawianego gatunku. Uściślając: Kochanowski tworzac Gadkę, myślał o broni palnej jako o rozstrzygnięciu docelowym, właściwym, ale ś w i a d omi e wykorzystał to, że zarówno jej budowa, jak i sposób obchodzenia się z nią (czyszczenie stemplem) odsyłają do wyobraźni erotycznej człowieka. Artysta wykazał się (doprawdy) niezwykłą maestria, grając znaczeniami poszczególnych słów, kreując obraz poetycki tak, by opierał się on na prostych skojarzeniach, zwodząc czytelnika, zacierając kształt opisywanego przedmiotu (pewne właściwości omawianego zwierzęcia zdają się pasować bardziej do rzyci, inne do penisa czy pochwy, jednak żadne $z$ nich nie jest zaopatrzone w komplet wymaganych cech i ostatecznie nie koresponduje $z$ „portretem” jednookiego zwierzęcia). A zatem: za Wenera skrywa się straszliwy Mars ${ }^{116}$ (armata lub ręczna broń palna ${ }^{117}$ ).

113 Zob. Żyguls ki, op. cit., s. 162-163.

114 Znawca dawnej artylerii polskiej, Łopatecki, autor prac tu przytaczanych, przychyla się również do opinii, że Gadka może mieć rozwiązanie militarne. Pogląd ten wyraził wprost w korespondencji, jaka podjęłam z nim w celu zasięgnięcia opinii eksperta.

115 Zob. I. Mi k s ow a, Kurek. Hasło w: Słownik polszczyzny XVI wieku, t. 11 (Red. M. R. M a y e n owa. Wrocław 1978), s. 576.

116 Bóstwa te były bardzo chętnie ze sobą łączone nie tylko przez poetów, ale przez artystów w ogóle. Przykład może stanowić niezwykły obraz S. Botticellego Wenus i Mars.

117 Na dłuższą metę rozróżnienie na broń lekką i ciężką nie ma jakiegoś większego znaczenia, gdyż oba rodzaje w czasach Kochanowskiego określane były również po prostu jako „strzelba”, a np. 
Dlaczego jeszcze przychylam się do rozwiązania militarnego, przyznając mu prymat nad rozwiązaniem erotycznym? Otóż: znów przekonują mnie argumenty wyłożone przez Pelca opisującego drogę Kochanowskiego na dwór królewski. Poezja miała stanowić klucz otwierający jego drzwi, o czym świadczyć mogą utwory upamiętniające tryumfy króla. Zygmunt August był zaś człowiekiem, który nie tylko zreformował polską artylerię, ale - należałoby rzec - ją wykreował. To za jego czasów ukazały się ustawy regulujące sprawy artyleryjskie na poziomie najbardziej podstawowym, a zatem dotyczaccym samych puszkarzy ${ }^{118}$. W działach i wszelkiej broni palnej król ten był wielce rozmiłowany, o czym świadczą nie tylko inskrypcje na armatach odlanych za jego panowania, ale i fakt, że monarcha pobudował (albo udoskonalił już istniejące) umocnienia i cekhauzy w strategicznych miejscach Rzeczypospolitej (Wilno, Tykocin, Kraków), zatrudniał świetnych rzemieślników-ludwisarzy, którzy zajmowali się odlewaniem dział, i dbał o to, by byli oni dobrze wynagradzani. Zamiłowanie do tego sprzętu zaszczepił mu ojciec, Zygmunt Stary. Upamiętnia go napis na arsenale królewskim, wystawionym w 1533 roku:

Sigismundus Rex Poloniae pace sapiens, bello tum strenuus quam felix, Pater Patriae merito appellatus, armamentarium hoc extruxit et bombardis tum a se factis, quam a Valacho devicto ereptis replevit A. D. 1533 [...]. [Zygmunt król Polski, mądry w czas pokoju, lecz w wojnie obrotny i szczęśliwy (tj. mający szczęście), zasługujący na miano Ojca Ojczyzny, wzniósł ten arsenał i wypełnił działami, zarówno wykonanymi z własnego rozkazu, jak i zdobytymi na Wołochach, w Roku Pańskim 1533.] ${ }^{119}$

August okazał się nieodrodnym synem swego ojca ${ }^{120}$. Ze zgromadzonych przez niego dział korzystali zreszta następni królowie. Część z nich odziedziczyli po Zygmuncie II i służyły im one w kolejnych wojnach, a część została przetopiona na nowe. Wszystko to odnotowują napisy armatnie:

Sigismundus Augustus materiam, formam omine fausto rex Vladislaus dedit anno 1639, Vladislavi Quarti sexto, procurante Paulo Grodzicki artilleriae regni praefecto. Me fecit Daniel Tym - „Zygmunt August dostarczył materiału, kształt nadał - pod dobrą wróżbą - król Władysław w roku 1639, Władysława Czwartego szóstym. Na polecenie Pawła Grodzickiego, dowódcy artylerii koronnej, odlał [mnie] Daniel Tym". [N s. 384]

Dlaczego więc Kochanowski, któremu, jak twierdził Pelc, zależało na tym, by swoją poezją przypodobać się królowi, nie miałby szturmować drzwi do jego dworu

hakownice czy nawet mniejsze od nich półhakownice, dzisiaj uznawane za odmianę broni ręcznej, Bielski w Sprawie rycerskiej zalicza do dział, co pokazuje przytoczony wcześniej cytat z tego dzieła.

K. Ło p a te c ki w książce „Disciplina militaris” $w$ wojskach Rzeczypospolitej do połowy XVII wie$k u$ (Białystok 2012, s. 135 n.) przedstawia szczegółowo historię artykułów wojskowych od epoki Zygmunta Starego. Ich twórcą był J. Ta r n ow s k i, który zawarł je w rozprawie Consillium rationis bellicae, uznawanej za najbardziej doniosłe dzieło z dziedziny polskiej myśli wojskowej (w języku polskim ukazała się w 1558 r.). Najwcześniejsze artykuły zostały wydane już w latach trzydziestych XVI wieku, wiadomo też, że uzupełniono je i zaktualizowano w związku z wyprawą poswolską w 1557 roku (zob. Ło pate cki, „Disciplina militaris” w wojskach Rzeczypospolitej do połowy XVII wieku, s. 156).

Ży gulski, op. cit., s. 185. Zob. też Gór ski, op. cit., s. 47.

120 Ojciec zadbał o gruntowne wojskowe wyszkolenie syna, nie zważając na jego młody wiek ani na wątłe zdrowie. Młody królewic bywał w obozach wojskowych i przygotowywał się do roli wodza pod okiem m.in. J. Tarnowskiego i A. Górki. Wspomina o tym Ł. G ó r n i c ki (Dzieje w Koronie Polskiej. Oprac. H. B a ry c z. Wyd. 2. Wrocław 1950, s. 10-11. BN I 124). 
za pomocą konceptu? Dlaczego - obok niewątpliwie kunsztownych ód czy elegii nie miałby mu podarować tego, w czym monarcha był prawdziwie rozkochany: armaty, sprytnie zakamuflowanej? Albo poręczniejszego, lżejszego muszkietu? Armata w czasie, kiedy tworzył Kochanowski, pozostawała symbolem najwyższej władzy i autorytetu, budziła zazdrość i pożądanie ${ }^{121}$. Posiadanie tego rodzaju broni równało się niewyobrażalnemu wprost majestatowi, przewyższającemu także olimpijskich bogów. Nawet więcej. Już za panowania Zygmunta Starego bywała ona poniekąd wcieleniem samego króla. Do Zygmunta Starego należało bowiem działo, które uosabiało jego majestat w sensie dosłownym, namacalnym: nosiło jego imię i skupiało w sobie cechy króla-gromowładcy:

Saeva, Sigismundus Primus rex, fulmina mitto. An solos superos fulmen habere putas - „Zygmunt Pierwszy król, miotam srogie pioruny. Czy sądzisz, że sami tylko niebianie posiadają pioruny?” [N s. 381]

Co jeszcze bardziej interesujące, Zygmunt I - armata miał też spiżowego „potomka”, „spadkobiercę”, nazwanego tak, jak prawdziwy syn króla: Augustus. A zatem armaty Zygmunt I oraz Augustus nie tylko uosabiały majestat władców z rodu Jagiellonów, ale odzwierciedlały ich linię sukcesyjną, następowały po sobie tak, jak syn następował po ojcu, obejmując tron:

Augustus vocor ex Augusto, rege Polonorum. Non tamen Augustum fulmen in ore fero [...]. [Nazywam się August od Augusta, króla Polaków. Niosę w paszczy jednak piorun nie boski / nie dostojny (w domyśle: nie tak dostojny, jak imię Augustus, które właśnie od przymiotnika o tym znaczeniu pochodzi, lub nie boski, jak ten $\mathrm{z}$ nieba, ale wywołany przez człowieka strzelającego $\mathrm{z}$ armaty; możliwa jest jednak także inna lekcja drugiego członu napisu, jeśli dodamy przecinek po wyrazie „Augustum”. Wówczas część tę można odczytać następująco: lecz nie Augusta, piorun niosę w paszczy". To ostatnie tłumaczenie jest na swój sposób konceptystyczne: jestem Augustem, jednak w środku mam nie Augusta, ale wybuchową „niespodzianke") ${ }^{122}$ ]. [N s. 381-382]

Obaj Jagiellonowie przypisywali zatem armatom wielkie znaczenie, widzieli w nich ucieleśnienie swej królewskiej potęgi. Ośmielam się sądzić, iż nie umknęło to uwadze Kochanowskiego. A ponieważ, obok potęgi i majestatu, przymiot króla winna stanowić mądrość, poeta armatę ukrył w zagadce. Wszak rozwiązywanie gadek to rozrywka królewska, w literaturze zaś renesansowej ideał króla-mędrca był popularny ${ }^{123}$. Twierdzę zatem, że to działo (ewentualnie strzelba ręczna: jego

121 Zob. Ło p a te cki, Ideowa wymowa ozdób armatnich z przełomu XVI i XVII wieku, s. 255-258, 265.

122 Za pomoc we właściwym odczytaniu tego fragmentu dziękuję Elwirze Buszewicz i Bartoszowi Awianowiczowi.

123 Tradycja ukazująca króla jako mędrca, któremu niestraszne nawet najtrudniejsze zagadki, jest wpisana choćby w cytowane wcześniej Historyje rzymskie, gdzie pojawiają się antagonistyczne postaci występnego króla Antyjocha oraz sprawiedliwego monarchy Apollona. Także Żywot Ezopa Fryga przedstawia apoteozę mędrca, który, co prawda, należy do szpetnych, lecz jednak jego mądrość przewyższa uczonych. Ezop jest biegły w rozwiązywaniu zagadek. Dzięki swej mądrości zostaje wywyższony do godności doradcy króla. Pełniąc tę funkcję, Ezop pomaga swemu panu. Rozwiązuje gadki przysyłane Ligurgowi przez adwersarzy. W ten sposób Ezop przyczynia się do zbudowania jego autorytetu wśród państw ościennych. Zob. Biern at z Lublin a, op. cit., k. F3:

U Ligurga króla mądrego,

Dostapił miejsca ważnego.

Bowiem naonczas krolowie 
mniejszy odpowiednik) jest bohaterem Gadki. Cóż bowiem wspanialszego - a przy tym: dowcipniejszego - mógłby dać Kochanowski w podarunku samemu królowi, jeśli nie armatę? I to taką, jakiej żaden z jego wspaniałych, świetnie wyposażonych cekhauzów dotąd nie posiadał - armatę poetycką, „odlaną” nie ze spiżu, ale ze słów. I to słowa przetrwały, przeminęły zaś spiże: miotające pioruny, jednookie bestie Zygmunta Augusta.

Abstract

EWA CYBULSKA-BOHUSZEWICZ Institute of Literary Research of the Polish Academy of Sciences, Warsaw

MARS HIDDEN BEHIND VENUS ONE MORE ATTEMPT AT SOLVING JAN KOCHANOWSKI'S "GADKA"

The text is one more attempt at solving the literary riddle contained in Jan Kochanowski's Gadka. The piece is ambiguous; efforts to dismantle it were made by such eminent scholars as Julian Krzyżanowski and Janusz Pelc, as well as by younger generation researchers, namely Joanna Duska, Radosław Grześkowiak, Maciej Eder. Each of them pondered over what "źwierzę o jednym oku" ("an animal with one eye") indeed was, and none of the analyses brought a concluding solution. The suggested proposals point to designates referring to erotic-scatological matter (male or female bottom, female sex organ, portable toilet) or to matters unconnected to it (firearm: a piece of ordnance or its smaller counterpart, a musket). It must be remembered that older generation researchers favoured the respectable (artillery) solutions while the younger one turned to the obscene.

A next solution to the riddle is contained in the article. It differs from the previous ones above all in that it considers not only Gadka's cultural and poetic contexts (sufficiently analysed by the abovementioned scholars), but it is an example of a detailed lexical examination which respects the meanings of individual words, phrases, and even syntactic elements present in the text. As a result, it is a semantic analysis, referring to the $16^{\text {th }} \mathrm{c}$. Polish language condition, i.e. to the texts produced at the time when Gadka was composed. The basic tool that facilitated such analysis was Stownik polszczyzny XVI wieku (Dictionary of $16^{\text {th }}$ Century Polish), containing excerpts from over 700 texts written at the times of the Polish Renaissance.

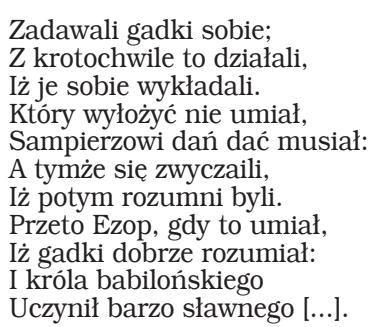

Nie sposób w tym miejscu nie wymienić również królów Edypa oraz Salomona, którzy potrafili zmierzyć się z najtrudniejszą (za)gadką czy problemem. 